\title{
Competition and microcredit interest rates: international evidence
}

\author{
Moh'd Al-Azzam ${ }^{1} \cdot$ Christopher Parmeter ${ }^{2}$
}

Received: 21 June 2018 / Accepted: 21 August 2019 / Published online: 3 September 2019

(c) The Author(s) 2019

\begin{abstract}
The limited number of existing papers that link competition among microfinance institutions (MFIs) and microcredit interest rates, provide inconclusive and counterintuitive results. This paper uses data from 1997 MFIs operating in 109 countries between the years 2003 and 2016 to construct three measures of competition and evaluate their impacts on interest rates. These measures reflect three different aspects of competition: geographical expansion, market concentration, and the marginal pricing. While the results for market concentration are inconclusive, the results for both geographical expansion and marginal pricing show an economically strong impact of competition on interest rates. Specifically, regardless of whether an MFI is a for-profit or nonprofit, we find meaningful evidence that competition reduces interest rates. Our findings evince that lower interest rates are needed if the microfinance movement is to continue to be relied on as an effective means to alleviate poverty.
\end{abstract}

Keywords Microfinance $\cdot$ Competition $\cdot$ Lerner Index $\cdot$ Microcredit interest rates . For-profit MFIs

JEL Classification D4 · G12 · G23 · F31 · F63

Moh'd Al-Azzam

malazzam@qu.edu.qa

Christopher Parmeter

c.parmeter@miami.edu

1 Department of Finance and Economics, Qatar University, Doha, Qatar

2 Department of Economics, University of Miami, Coral Gables, USA 


\section{Introduction}

Microfinance institutions (MFIs) operate under significant financial constraints. They serve the unbankable, face high risks of default, provide small loans, operate in remote areas, use labour intensively, and strive to reduce reliance on subsidies to achieve financial sustainability. As such high interest rates for MFIs are perceived to be inevitable. However, the impact of high interest rates on the poor has become a widespread concern. Problems associated with high interest rates include the reduction of both borrowers' surpluses and the demand for, and uptake of, microfinance services, inability to keep up with interest payments, over-indebtedness, exacerbation of financial burdens, social stresses, and the reduction of the overall well-being of borrowers. Rosenberg et al. (2009), Van Rooyen et al. (2012), Dehejia et al. (2012), and Sinclair (2012) conclude that high interest rates are one of the central reasons why MFIs may fail to ensure the wellbeing of the poor and serve as a poverty alleviation tool.

Classical economics asserts the importance of competition in markets as an alternative to government intervention through, for example, interest rate ceilings (Helmes and Reille 2004; Miller 2013). In general, competition is believed to promote allocative and productive efficiency, which leads to lower costs of microcredit. While the initial movement of microfinance as a poverty alleviation tool has received substantial support from non-government organisations (NGOs), donors, social investment funds, and subsidies, the increase in profit opportunities has gradually moved microfinance into the provision of financial services to the poor on a commercial basis. With commercialisation comes competition that was deemed inevitable following the entrance of for-profit MFIs and the continuing transformation of many NGOs into for-profit MFIs. Competition is gradually becoming an important facet of microfinance (Porteous 2006).

Unlike typical industries, there exists a mixture of for-profit and nonprofit MFIs. While for-profit MFIs seek to maximise profit, nonprofit MFIs tend to maximise social objectives such as serving the poorest population, maximising outreach to borrowers, and empowering women. For-profit MFIs may compete among each other to maximise profits and nonprofit MFIs may compete among each other to maximise social objectives. Despite this, one common objective of both for-profit and nonprofit MFIs is to maximise the number of borrowers (even though for-profit MFIs may target more reliable borrowers). How interest rates are set by for-profit and nonprofit MFIs may have important consequences on the number of borrowers served. In addition, corporate social responsibilities of forprofit MFIs may induce them to compete with nonprofit MFIs in providing loans at concessional rates for health, education, and housing purposes. While studies on the impact of competition on microfinance in general remain very limited, the impact of competition on interest rates has been further overlooked.

The structure-conduct-performance paradigm would predict that MFIs with more sources of monopoly power would engage in anticompetitive behaviour, such as charging higher interest rates (Bain 1956). In this, a competitive environment in microfinance may contribute to the promotion of allocative and 
productive efficiency, which lowers cost and interest rates. One side of the argument is that competition may lead to lower standards of screening and monitoring, increased asymmetry of information, a weaker MFI-borrower relationship, multiple loan taking, over-indebtedness, and high default rates (McIntosh and Wydick 2005; McIntosh et al. 2005; Vogelgesang 2003; Schicks and Rosenberg 2011; Assefa et al. 2013; Bardsley and Meager 2012). If defaults on loans rise, then MFIs may respond by increasing interest rates. The theoretical implications of de Quidt et al. (2018) suggest this direction. They find that competition reduces MFIs' use of joint liability, which in turn reduces repayment rates, increases interest rates. However, higher interest rates may affect the riskiness of the pool of loans by crowding out safer borrowers or by inducing borrowers to invest in riskier projects, both of which may lower profits of the MFIs. Therefore, MFIs may reduce the number of loans given and introduce stricter credit standards instead of increasing interest rates (Stiglitz and Wiess 1981). Consequently, the impact of competition on interest rates is not definite.

The empirical studies that examine the impact of competition on interest rates have reached inconclusive and counterintuitive results. Baquero et al. (2018) examine the impact of competition on interest rates and portfolio quality for both nonprofit and for-profit MFIs using the Herfindahl-Hirschman Index. The authors find that in less concentrated markets, for-profit MFIs charge lower interest rates and have better portfolio quality and that nonprofit MFIs are insensitive to changes in market concentration. Mersland and Strøm (2009) construct a measure of competition based on the challenge of competition as perceived by the MFIs and conclude that interest rates respond positively to higher levels of competition. Depending on the profit status of the MFI and using the number of MFIs active in each country in 2009 as a measure of competition, Roberts (2013) finds that competition among nonprofit MFIs reduces interest rates, while competition among for-profit MFIs increases interest rates.

Studies that evaluate the impact of competition on interest rates are lacking in various aspects. First, evidence on competition in microfinance is scarce. Second, the results of these studies are strongly inconclusive. One main reason for this might be the adoption of a single measure of competition in each of these studies. In addition, the various measures considered may not necessarily reflect intensity of competition and potential market power of the MFIs. Third, the literature reveals little on the impact of competition among for-profit MFIs and nonprofit MFIs on interest rates. The current results on the impact of competition among for-profit MFIs and nonprofit MFIs and that more competition increases interest rates seem to strongly contradict the structure-conduct-performance. Fourth, a structured analysis of the extent to which competition prevails and how it affects interest rates is still quite limited.

This paper considers the impact of three distinct measures of competition on interest rates using data collected from the Microfinance Information Exchange (MIX) from 1997 MFIs between the years 2003 and 2016. These measures are based on the geographical expansion through the use of the number of branch offices of an MFI relative to the total number of branch offices of all MFIs in the country, market concentration based on a gross loan portfolio, and the difference between price and 
marginal cost (i.e. the Lerner Index). These measures give different signals on the evolution of competition over time. Although the results for market concentration seem to be inconclusive (but consistent with the nascent literature), the results for the number of branch offices and the Lerner Index show a consistent impact of competition on interest rates; specifically, increased competition reduces interest rates charged by for-profit and nonprofit MFIs.

The paper proceeds as follows: Sect. 2 presents the data. Section 3 outlays the empirical model, explains the variables used, and develops alternative measures of competition. Section 4 presents the estimation methods, and Sect. 5 presents the results and discussion. Finally, Sect. 6 presents several concluding thoughts and offers policy recommendations.

\section{Data}

There are more than 3000 MFIs reporting to the MIX Market. Data for MFIs date back to 1999. The MIX Market classifies MFIs into diamonds according to the availability and quality of data provided by the MFIs. Diamonds range from 1 to 5 where a higher number indicates more transparent and reliable data. To evaluate the overall impact of competition, all MFIs are included regardless of their classifications. To address the quality and availability of data, MFIs with three or less diamonds are also used, and the subsequent results were essentially the same. Data on macroeconomic variables and interest rate ceilings are gathered from the World Bank and Naimbo and Gallegos (2014), respectively.

The full data set contains information on 2944 MFIs operating in 122 countries with 17,819 annual observations. Due to some missing values and data trimming, data for 947 MFIs were dropped. Therefore, the final unbalanced sample used in the empirical analysis contains information on 1997 MFIs operating in 109 countries for the period 2003-2016. The breakdown by region is 504 from Latin America and the Caribbean, 322 from South Asia, 420 from Africa, 369 from Eastern Europe and Central Asia, 315 from East Asia and the Pacific, and 67 from the Middle East and North Africa. All MFIs are included regardless of their legal status: nonprofit institutions (e.g. NGOs), nonbank financial institutions, credit unions/cooperatives, rural banks, and one under the category of "other". The breakdown of MFIs by type is 589 NGOs, 638 nonbank financial institutions, 412 credit unions/cooperatives, 177 banks, 129 rural banks, and 52 under the category "other". Fifty-nine per cent of these MFIs are registered as nonprofit. To account for the problem of outliers, the lowest and highest $2.5 \%$ of the values of the variables used are dropped.

The data has three major caveats. First, the data used in this paper is unadjusted for subsidies, inflation, cost of funds, or loan loss provisioning and thus not in conformity with international accounting standards making comparisons across MFIs uncertain (Cull et al. 2009). However, since adjustment of the data requires several data points as inputs, the sample size of the unadjusted data is expected to be larger than that for the adjusted data. Second, because reporting to the MIX Market is voluntary, analysis based on the MIX data is susceptible to self-selection bias. This bias can take two forms. First, MFIs reporting to the MIX Market are likely to be 
different from MFIs that are not reporting. Second, MFIs may report some indicators for some years but not for others. MFIs that do report to the MIX Market might be more successful than the ones who do not and MFIs that report selective indicators might be reporting the more promising ones. Bauchet and Morduch (2010a, b) note that successful MFIs with adequate staff and information systems volunteer more, that financial indicators are reported more than social indicators, and that reporting is correlated with the institutions' region, mission, and size. These patterns of reporting can potentially impact the accuracy of our measures of competition, the first two in particular. Finally, the legal status of an MFI can vary over time. The change in the legal status can affect many of the performance indicators of the MFI (D'Espallier et al. 2017). However, the MIX Market database that we use does not reflect changes in the profit status of the MFI. If an MFI is currently registered as a nonbank financial institution, it will be recorded as such for all years even though it could have been a non-government organisation in previous years. Therefore, we treat the legal status of the MFIs as time invariant. Nevertheless, Wagennar (2014) uses the MIX Market dataset that includes 1558 MFIs and found that only 75 MFIs transformed to a different legal status. This relatively small number of transformed MFIs is highly unlikely to affect the results of this paper. The major strength of the MIX Market data is the large number of worldwide participating MFIs and its wide use in the microfinance empirical literature.

\section{Variables: description and construction methodology}

Our main focus is the impact of various measures of competition on microcredit interest rates. The dependent variable is the real yield on gross loan portfolio (and thereafter interest rate) defined as:

$$
\text { Interest Rate }=\frac{\text { Yield on Gross Portfolio (nominal) }- \text { Inflation Rate }}{1+\text { Inflation Rate }}
$$

where yield on gross portfolio (nominal) is financial revenue from loans compared to gross loan portfolio. Microcredit interest rates include fees and commissions on the gross loan portfolio and income from late fees and penalties.

Table 1 presents variable description and summary statistics of the dependent and independent variables. In addition to a time trend, the independent variables are classified into three groups: MFI-specific, country-specific, and competition variables. The time effect (Trend) is the time span between the years 2003 and 2016 for each MFI. Figure 1 shows the variation in the worldwide average microcredit interest rate between the years 2003 and 2016. The overall worldwide microcredit interest rates are hardly falling over time. We do note that average worldwide interest rates were falling steadily until the global financial crisis, at which point they increased about 5 percentage points and have remained stable since $2010 / 2011$. 


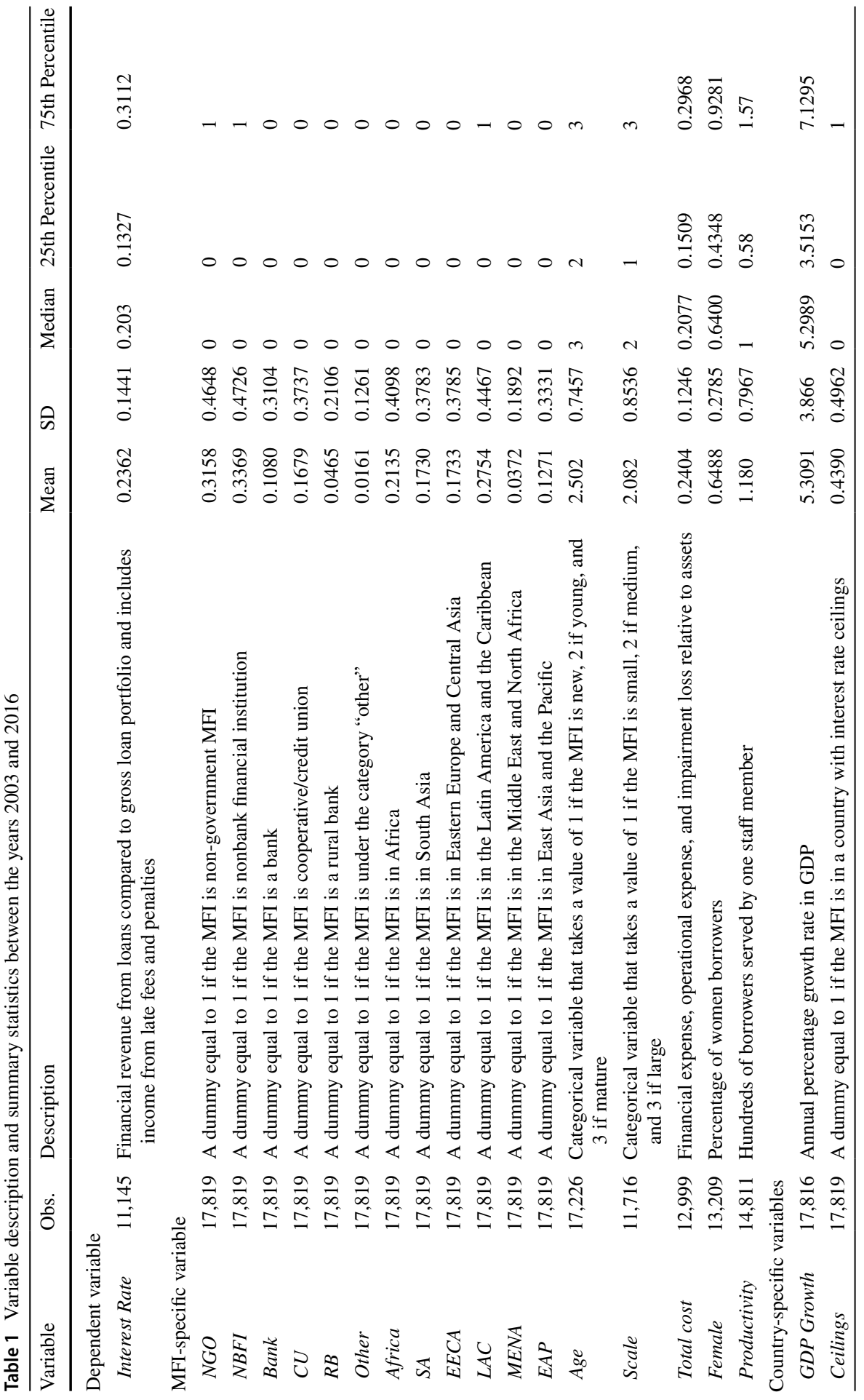




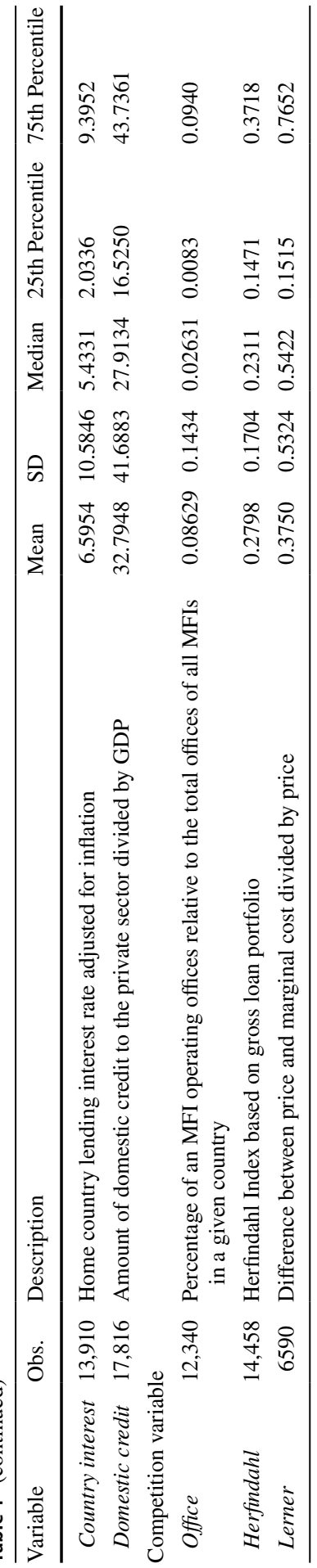


Interest Rate

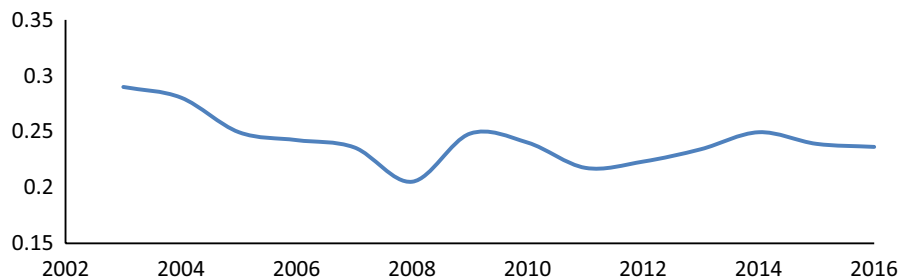

Fig. 1 Worldwide average interest rates between the years 2003 and 2016

\subsection{MFI-specific variables}

Two sets of dummy variables are used to control for variations in interest rates within MFIs and regions. The first includes dummy variables for non-government MFIs (NGO), nonbank financial institutions (NBFI), banks (Bank), credit union/cooperatives (CU), rural banks (RB), and one classified as "other". According to the MIX glossary, NGOs are organisations registered as nonprofit for tax purposes. They are usually non-deposit taking and not regulated by supervisory agencies. Banks are regulated financial intermediaries and may provide a number of financial services such as deposit taking and money transfers. NBFIs are institutions that provide similar services to those of regular banks but usually have lower capital requirements and limited financial service offerings. Cooperative/Credit Unions are non-regulated, nonprofit, financial intermediaries that offer a range of financial services including deposit taking for the benefit of its members. Rural banks are institutions that serve clients in non-urban areas generally designed for agricultural-related activities.

The second set includes dummy variables for South Asia $(S A)$, Eastern Europe and Central Asia (EECA), Latin America and the Caribbean (LAC), Africa (Africa), Eastern Asia and the Pacific (EAP), and the Middle East and North Africa (MENA).

Two variables, Age and Scale, are used to measure the impact of economies of scale and learning effects. Age takes a value of 1 if the MFI is new, a value of 2 if the MFI is young and a value of 3 if the MFI is mature. ${ }^{1}$ New MFIs usually start with high costs. As MFIs mature, they become larger; by trial and error, they may have a better ability to lower costs and interest rates. Therefore, it is hypothesised that the relationship between Age and interest rates takes an inverted U-shape, and the analysis includes a quadratic in Age, Agesq. Scale is a categorical variable based on gross loan portfolio in USD. We adopt this measure from the MIX Market. It takes a value of 1 if the MFI is small, 2 if the MFI is medium, and 3 if the MFI is large. ${ }^{2}$ Higher values reflect more opportunities for economies of scale and, therefore, lower interest rates.

\footnotetext{
1 According to the MIX Market, an MFI is new if the difference between the year it started its operation and the year it submitted its data to the MIX Market is between 1 and 4 years, young if the difference is between 5 and 8 years, and mature if the difference is greater than 8 years.

2 According to the MIX Market, an MFI is large if the gross loan portfolio is 8 million or more for MFIs in Africa, Asia, EECA, and MENA and 15 million or for MFIs in LAC. An MFI is medium if the gross loan portfolio is between 2 million and 8 million for MFIs in Africa, Asia, EECA, and MENA and between 4 million and 15 million for MFIs in LAC. Finally, an MFI is small if the gross loan portfolio is less than 2 million for MFI is in Africa, Asia, EECA, and MENA and less than 4 million in LAC.
} 
Practitioners and researchers have documented links between the gender of the microfinance borrowers and the performance of the MFIs (Khandker et al. 1995: Kevane and Wydick 2001; Armendariz De Aghion and Morduch 2005; Emran et al. 2011; D'Espallier et al. 2013a, b; Basharat et al. 2015). To capture the impact of gender on interest rates, the percentage of female borrowers (Female) served by each MFI is used as an additional control variable. Female is the number of active borrowers who are women divided by the total number of active borrowers.

The cost of loans and the productivity of staff members are two major factors that may influence the interest rates of an MFI. To capture these effects, we use the sum of the financial expense, operational expense and impairment loss relative to the value of assets (Total cost) and the number of active borrowers divided by the number of personnel (Productivity) as measures of cost and productivity. Higher costs are expected to be associated with higher interest rates, and higher productivity is expected to be associated with lower interest rates. ${ }^{3}$

\subsection{Country-specific variables}

The interaction between country-level macroeconomic variables and microfinance financial indicators has been documented by different studies (Honohan 2004; Gonzalez 2007; Hermes et al. 2018; Ahlin et al. 2011; Mersland and Strøm 2013; Buera et al. 2012; de Quidt et al. 2018). Real GDP growth defined as the annual percentage growth in real GDP is used as an indicator of economic growth. It is a summary statistic of the overall developmental, institutional, and technological progress. High economic growth may increase micro-enterprise returns and the demand for microcredit, allowing MFIs to increase interest rates. On the other hand, high growth may raise household incomes and reduce the demand for microcredit and interest rates. Interest rates are unlikely to adjust instantaneously to overall economic growth. Therefore, the impact of 1-year lagged GDP growth on interest rates is considered. Often, various types of interest rates move together in the same direction. We would expect real interest rates in the home country to increase microcredit interest rates. We therefore introduce the real interest rate in the home country (Country interest) as an additional regressor; the lending interest rate adjusted for inflation as measured by the GDP deflator. The level of development of the financial sector is expected to have a significant impact on the microfinance industry in general and microcredit interest rates specifically. A more developed financial sector is expected to be associated with lower costs to MFIs, higher level of competition, and higher levels of financial inclusion, all of which

\footnotetext{
3 There are other variables that can affect microcredit interest rates. For example, subsidies and deposits can be perceived as cheap sources of funds and therefore subsidized, and deposit mobilising MFIs are expected to offer microcredit at lower interest rates. We use current year donated equity to gross loan portfolio and total amount of deposits relative to gross loan portfolio in the preliminary empirical work. The results show little evidence on the impact of deposits while this evidence is stronger for subsidies. The inclusion of subsidies led to a sharp decrease in the sample size and therefore dropped from the analysis.
} 
reduce interest rates. We include a proxy for the overall financial development of the country (Domestic credit): the amount of domestic credit to the private sector divided by GDP. ${ }^{4}$ Many policy responses to protect borrowers include imposing obligatory ceilings on interest rates. Interest rate ceilings in the data sample apply to MFIs that operate in 32 countries (Naimbo and Gallegos 2014). ${ }^{5}$ Therefore, MFIs operating in countries that impose interest rate ceilings are expected to charge lower interest rates. A dummy (Ceilings) equal to one is used if the MFI is in a country that imposes interest rate ceilings. ${ }^{6}$

\subsection{Competition variables}

The focal element of this work is the impact of competition on interest rates. To empirically assess the impact of competition, three measures for competition are constructed. These measures are based on three different aspects of competition: the geographical expansion of an MFI, market concentration and the difference between price and marginal cost.

\subsubsection{Geographical expansion}

The first measure of competition reflects the geographical presence of an MFI. If an MFI competes for more borrowers, it must acquire specific infrastructure, such as branch offices. Therefore, the number of branch offices of an MFI relative to the total number of offices of all MFIs in a given country is used as a measure of competition (Office). An MFI may open a new branch office to penetrate an underserved area or to prevent competitors from "poaching" existing borrowers in a particular area. This may lead to more concentrated markets and the failure of some small MFIs. Therefore, a positive sign of the coefficient on Office is expected. That is, as an MFI expands through more branch offices relative to other MFIs, it would gain more monopoly power, enabling it to charge higher interest rates.

\footnotetext{
${ }^{4}$ Other potential macroeconomic variables can affect microcredit interest rates; country's risk premium is an example. The World Bank measure of risk premium defined as the interest rate charged by banks on loans to private sector customers minus the "risk free" treasury bill interest rate at which short-term government securities are issued or traded in the market show a positive impact on microcredit interest rates. Inclusion of this variable in the analysis, however, reduces the sample size significantly and therefore dropped from the analysis.

5 These countries are Ethiopia, Ghana, Guinea, Namibia, Nigeria, South Africa, Sudan, Zambia, China, the Philippines, Thailand, Vietnam, Armenia, Poland, Turkey, Bolivia, Brazil, Chile, Colombia, Ecuador, Guatemala, Honduras, Nicaragua, Paraguay, the Dominican Republic, Venezuela, Egypt, Syria, Tunisia, Bangladesh, India and Pakistan.

${ }^{6}$ Data on interest rates ceilings are obtained from Naimbo and Gallegos (2014) who find that at least 76 counties around the world use different forms of interest rates caps. The authors have gathered this information from eight different sources. We assume that a country has interest rate ceiling and maintain it for the period of our sample (2003-2016) if it is reported by Naimbo and Gallegos (2014).
} 


\subsubsection{Herfindahl Index}

A common measure of market concentration, the Herfindahl Index (Herfindahl), is used as an alternative measure of competition. The Herfindahl Index is calculated by squaring the market share of the gross loan portfolio of each MFI that is competing in a country in each year and then adding across these squared shares. The expected sign of the coefficient on Herfindahl is positive. A larger value of the Herfindahl index conveys greater concentration. A value close to zero indicates a purely competitive microfinance industry, and a value of one indicates a purely monopolistic industry. In general, a value less than 0.15 indicates low concentration, and a value above 0.25 indicates high concentration. ${ }^{7}$ The mean value of the Herfindahl Index in the current sample is 0.28 , indicating the presence of highly concentrated microfinance markets across countries. ${ }^{8}$

\subsubsection{Lerner Index}

As with any measure of competition, both Herfindahl and Office have drawbacks. For example, it may arise that two MFIs have the same number of branch offices and/or the same Herfindahl values but operate in isolated geographic areas. For many large (geographically or societally) countries, such as India, different MFIs can focus on different areas. Thus, while these measures may indicate strong competition among MFIs in a country, it is a possibility that MFIs might also be operating in different areas with no effective competition. In addition, the Herfindahl Index can be misleading because higher concentration does not necessarily imply a lack of competition, Bikker and Haaf (2002).

To mitigate against this potential situation, a third alternative measure of competition, the Lerner Index (Lerner), is constructed. This index is ratio of the MFI's markup (the difference between price and marginal cost) to price. The expected sign of the coefficient on the Lerner Index is positive. The Lerner Index has been widely used in the banking literature (Angelini and Cetorelli 2003; Fernandez de Guevara et al. 2005; Maudos and Fernandez de Cuevara 2007; Kasman and Kasman 2015). Assefa et al. (2013) were the first to use the Lerner Index in the microfinance literature. Clearly, the appropriateness of using this measure depends on the accuracy of measuring marginal cost and price when there is almost always ambiguity as to how to construct an institution's marginal cost (e.g. risk provision and subsidies) and price, particularly in the banking industry.

To estimate the marginal cost, a translog cost function is first estimated, where cost is a function of output and the prices of three input factors:

\footnotetext{
${ }^{7}$ For example, the U. S. Department of Justice and Federal Trade Commission use these cutoffs as a guideline for horizontal mergers.

${ }^{8}$ We have also used the Herfindahl Index based on the number of active borrowers to reflect the dual mission of the MFIs (Hartarska et al. 2010). The results obtained from this measure are similar to the results obtained from the Herfindahl Index based on the gross loan portfolio.
} 


$$
\begin{aligned}
\ln C_{i, t}= & \beta_{0}+\beta_{1} \ln Q_{i, t}+\beta_{2} \ln w_{i, t}+\beta_{3} \ln r p h_{i, t}+\beta_{4} \ln r f_{i, t}+\frac{1}{2} \beta_{5}\left(\ln Q_{i, t}\right)^{2}+\frac{1}{2} \beta_{6}\left(\ln w_{i, t}\right)^{2} \\
& +\frac{1}{2} \beta_{7}\left(\ln r p h_{i, t}\right)^{2}+\frac{1}{2} \beta_{8}\left(\ln r f_{i, t}\right)^{2}+\beta_{9} \ln Q_{i, t} \ln w_{i, t}+\beta_{10} \ln Q_{i, t} \ln r p h_{i, t} \\
& +\beta_{11} \ln Q_{i, t} \ln r f_{i, t}+\beta_{12} \ln w_{i, t} \ln r p h_{i, t}+\beta_{13} \ln w_{i, t} \ln r f_{i, t}+\beta_{14} \ln r p h_{i, t} \ln r f_{i, t} \\
& +\beta_{15} \ln \text { Risk }_{i, t}+\frac{1}{2} \beta_{16}\left(\ln \text { Risk }_{i, t}\right)^{2}+\beta_{17} \ln \text { Risk }_{i, t} \ln Q_{i, t}+\beta_{18} \ln \text { Risk }_{i, t} \ln w_{i, t} \\
& +\beta_{19} \ln \text { Risk }_{i, t} \ln r p h_{i, t}+\beta_{20} \ln \text { Risk }_{i, t} \ln r f_{i, t}+\beta_{21} \text { Trend }_{i, t}+\beta_{22}\left(\text { Trend }_{i, t}\right)^{2} \\
& +\beta_{23} \text { Trend }_{i, t} \ln Q_{i, t}+\beta_{24} \text { Trend }_{i, t} \ln w_{i, t}+\beta_{25} \text { Trend }_{i, t} \ln r p h_{i, t}+\beta_{26} \text { Trend }_{i t} \ln r f_{i, t} \\
& +\beta_{27} \text { Trend }_{i, t} \ln \text { Risk }_{i, t}+\beta_{28} \text { MFItype }_{i, t}+\beta_{29} \text { Savingdummy }_{i, t}+\beta_{30} \text { Country }_{i, j} \\
& +\varepsilon_{i, t}+v_{i, t}
\end{aligned}
$$

In the equation above, $C_{i, t}$ represents the total cost for MFI $i$ at time $t$, which includes financial expense, operational expense, and impairment loss (Cost). $Q$ represents output measured by gross loan portfolio (Gross Loan Portfolio), w represents the price of labour measured as the ratio of the personnel expense to the number of personnel (Plabor), rph represents the price of physical capital measured as the administrative expense relative to the net fixed assets (Pcapital), and $r f$ represents the price of financial capital measured as the interest expense on borrowings relative to total borrowings (Pfcapital). Following Hartarska et al. (2013), we include credit risk (Risk) to account for portfolio quality and a time trend (Trend) to account for technological change. Risk is the ratio of loans greater than 30 days past due relative to the gross loan portfolio. To control for differences in the cost functions of different types of MFIs, a vector of dummies for the type of the MFI (MFItype) is included: $N G O, N B F I, B a n k, C U, R B$, and Other. The dummy for $N G O$ is used as the baseline variable. Providing saving services may necessitate minimum balance requirements, financial and administrative obligations all of which may increases costs. To account for the cost of providing saving, we include a dummy for MFIs that provide deposit services (Saving).

The term $\varepsilon$ is the noise component, $v$ is the cost inefficiency component, and $\beta s$ are parameters to be estimated. Homogeneity in input prices requires the following restrictions on Eq. (1):

$$
\begin{gathered}
\beta_{2}+\beta_{3}+\beta_{4}=1 ; \\
\beta_{9}+\beta_{10}+\beta_{11}=0 ; \\
\beta_{12}+\beta_{13}+\beta_{14}=0 ; \\
\beta_{18}+\beta_{19}+\beta_{20}=0 ; \\
\beta_{24}+\beta_{25}+\beta_{26}=0 ;
\end{gathered}
$$

These restrictions are imposed by dividing input prices and total cost by the price of physical capital. While the translog cost function can be estimated directly, 
estimating it jointly with share equations can improve the efficiency of estimation (Hartarska et al. 2013). By differentiating the translog cost function with respect to input prices and employing Shephard's Lemma, we obtain the following cost share equations:

$$
\begin{aligned}
s_{w}= & \frac{\partial \ln C_{i, t}}{\partial w_{i, t}}=\beta_{2}+\beta_{6} \ln w_{i, t}+\beta_{9} \ln Q_{i, t}+B_{12} \ln r p h_{i, t}+\beta_{13} \ln r f_{i, t} \\
& +\beta_{18} \ln \text { Risk }_{i, t}+\beta_{24} \text { Time }_{i, t} \\
s_{r p h}= & \frac{\partial \ln C_{i, t}}{\partial \ln r p h_{i, t}}=\beta_{3}+\beta_{7} \ln r p h_{i, t}+\beta_{10} \ln Q_{i, t}+\beta_{12} \ln w_{i, t}+\beta_{14} \ln r f_{i, t} \\
& +\beta_{19} \ln \operatorname{Risk}_{i, t}+\beta_{25} \text { Time }_{i, t} \\
& \frac{\partial \ln C_{i, t}}{\partial \ln r f_{i, t}}=\beta_{3}+\beta_{8} \ln r f_{i, t}+\beta_{11} \ln Q_{i, t}+\beta_{13} \ln w_{i, t}+\beta_{14} \ln r p h_{i, t} \\
& +\beta_{20} \ln \text { Risk }_{i, t}+\beta_{26} \text { Time }_{i, t}
\end{aligned}
$$

where cross-equation parameters restrictions are imposed. We operationalise the cost share equations by dropping the cost share equation of physical capital leaving us with a non-singular system. The translog cost function and the cost share equations are estimated using seemingly unrelated regression.

Taking the derivative of Eq. (1) with respect to output (elasticity of total cost with respect to output) yields:

$$
\frac{\partial \ln C_{i, t}}{\partial \ln Q_{i, t}}=\left(\frac{\partial C_{i, t}}{\partial Q_{i, t}}\right)\left(\frac{Q_{i, t}}{C_{i, t}}\right)
$$

The first term in Eq. (2) is the marginal cost (MC). Equation (2) therefore can be rewritten as:

$$
\mathrm{MC}_{i, t}=\left(\frac{\partial \ln C_{i, t}}{\partial \ln Q_{i, t}}\right)\left(\frac{C_{i, t}}{Q_{i, t}}\right)
$$

Using Eq. (1), the first term of Eq. (3) is:

$$
\frac{\partial \ln C_{i, t}}{\partial \ln Q_{i, t}}=\beta_{1}+\beta_{5} \ln Q_{i, t}+\beta_{9} \ln w_{i, t}+\beta_{10} \ln r p h_{i, t}+\beta_{11} \ln r f_{i, t}+\beta_{17} \ln \text { Risk }_{i, t}+\beta_{23} \text { Time }_{i, t}
$$


Substituting Eq. (4) into Eq. (3) yields:

$$
M C_{i, t}=\frac{C_{i, t}}{Q_{i, t}}\left(\beta_{1}+\beta_{5} \ln Q_{i, t}+\beta_{9} \ln w_{i, t}+\beta_{10} \ln r p h_{i, t}+\beta_{11} \ln r f_{i, t}+\beta_{17} \ln \text { Risk }_{i, t}+\beta_{23} \text { Time }_{i, t}\right)
$$

Once Eq. (1) is estimated, the estimated coefficients $\left(\beta_{1}, \beta_{5}, \beta_{9}, \beta_{10}, \beta_{11}, \beta_{17}, \beta_{23}\right)$ and the observed variables for total cost (Cost), output (Gross Loan Portfolio), and input prices (Plabor) and (Pfcapital) are used to calculate the marginal cost in Eq. (5).

Once the marginal cost is estimated, the Lerner Index is then computed as:

$$
L_{i, t}=\left(\frac{P_{i, t}-M C_{i, t}}{P_{i, t}}\right)
$$

where $L_{i, t}$ is the Lerner Index of MFI $i$ at time $t, M C$ is the marginal cost as estimated above, and $P$ is the output price calculated as the ratio of financial revenue from loans to gross loan portfolio. ${ }^{9}$ Price excludes both fees and commissions on the gross loan portfolio and income from the late fees and penalties. Table 2 presents the summary statistics of the variables used to estimate the translog cost function, as well the as price of output (Price) as defined above.

Table 3 shows the description of the variables and summary statistics for Price, Marginal Cost and the Lerner Index.

The evolution of competition as measured by the Lerner Index as well as by Office and Herfindahl is shown in Fig. 2. The MFIs' shares in terms of office branches were falling until 2008 then began rising while the Herfindahl Index has been slightly falling over time in non-monotonic manner. ${ }^{10}$ Unlike the Herfindahl Index, the Lerner Index shows that the overall monopoly power of the MFIs has been rising overtime. This is consistent with Kar (2016) who, using the Boone indicator, finds that competition was falling in major countries such as Bangladesh and Bolivia.

The pairwise correlation between the worldwide trends in Herfindahl and Office is 0.24 while it is -0.59 and -0.47 between the Lerner Index and Office and between the Lerner Index and Herfindahl, respectively. The positive correlation between Office and Herfindahl is expected but the negative correlation between the Lerner Index and Office and between the Lerner Index and Herfindahl is not. In the preliminary empirical work, we have noticed that MFIs that have high values of Office and high values of Herfindahl serve less women. The pairwise correlations between the percentage of female borrowers and the Lerner Index, Office, and Herfindahl are $0.12,-0.13$ and -0.18 , respectively. MFIs that have higher shares of office branches and higher shares in gross loan portfolio seem to serve fewer female borrowers, while MFIs that have higher Lerner indices are associated with more women

\footnotetext{
9 We have also used the number of active borrowers as a measure of output (Caudill et al. 2012) in the cost function. The marginal cost and the price of output obtained by dividing the total financial revenue by the number of active borrowers are used to compute the Lerner Index. The results obtained from this measure are similar to the results obtained when using gross loan portfolio as an output.

${ }^{10}$ For more details on the impact of the global financial crisis on microfinance, see Bella Di (2011).
} 


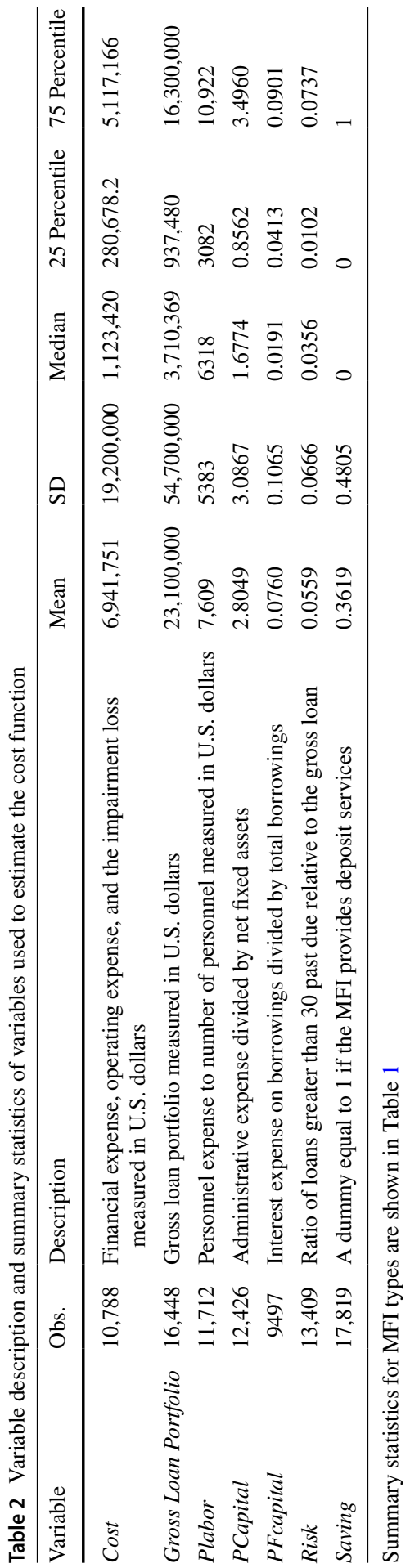




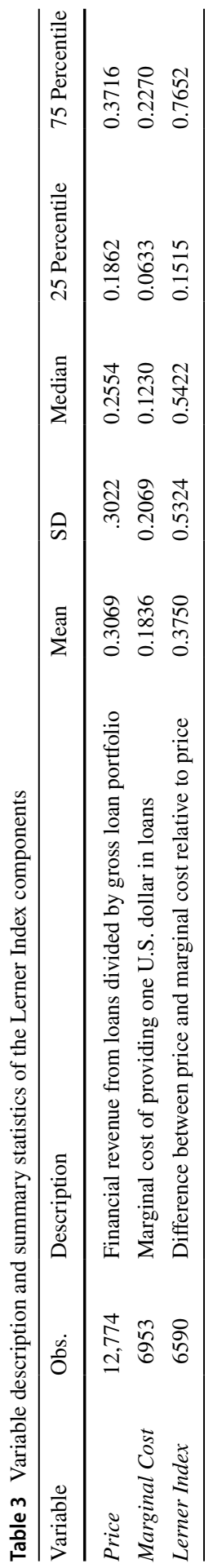



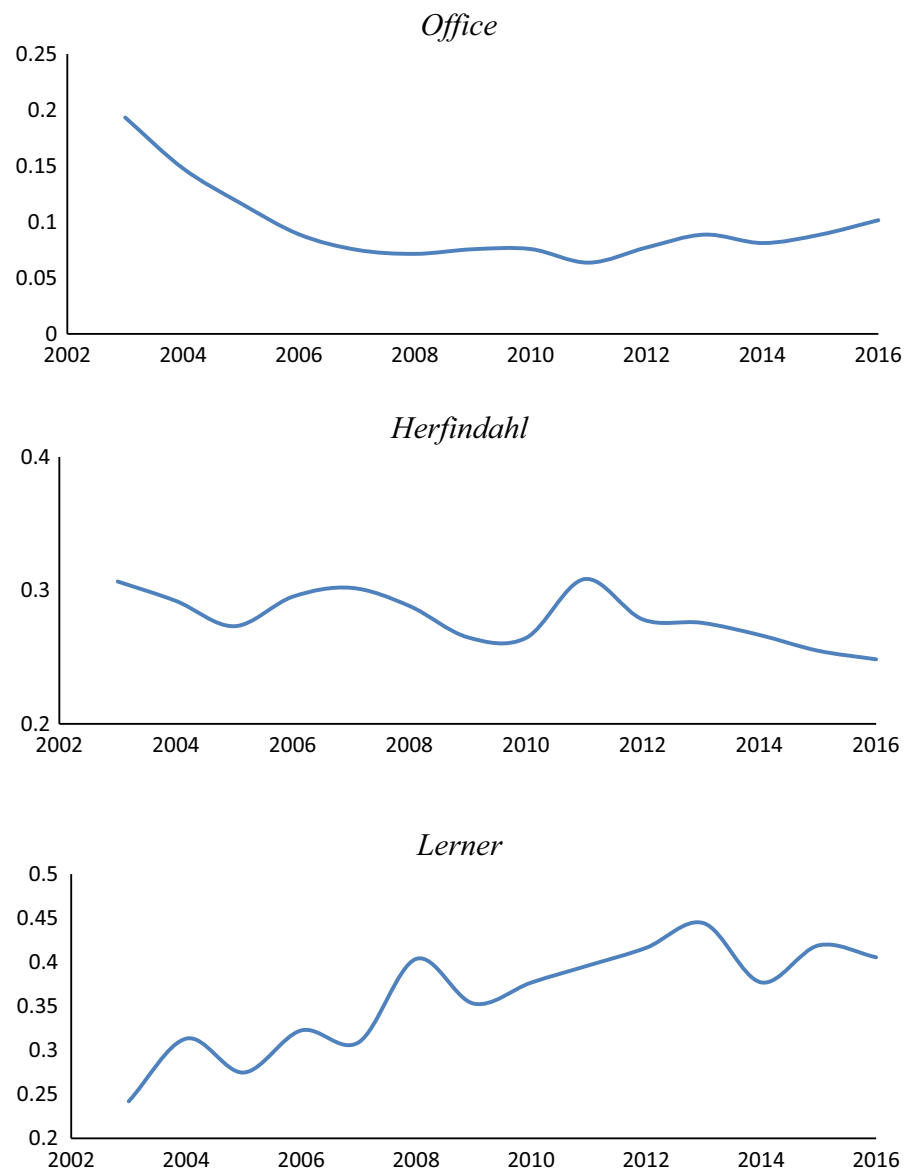

Fig. 2 Evolution of competition as measured by Office, Herfindahl, and Lerner indices

borrowers. MFIs with higher values of Office and Herfindahl serve less women who usually have less access to formal financial services (Emran et al. 2011), receive smaller loans and pay higher interest rates compare to men (D'Espallier et al. 2013a, b). Higher interest rates and smaller loans, which reduce MFIs' scale economies, both lower the value of the Lerner Index.

\section{Estimation}

With panel data, it is possible to control for some forms of observation specific heterogeneity. At issue is the nature of how this heterogeneity is treated within the conditional mean. The most commonly considered settings are the fixed effects (FE) and random effects (RE) framework. In the RE framework, independence between the explanatory variables and the unobserved individual heterogeneity is assumed. If 
this assumption is satisfied, the random effects estimator is unbiased and efficient. If the unobserved heterogeneity is correlated with the explanatory variables, then the fixed effects framework is preferred. The choice between the FE and RE frameworks can easily be tested through the Hausman test, though, given the consistency of the FE estimator under the RE framework, Guggenberger (2010) recommends deploying the FE estimator for any subsequent inference.

Use of the fixed effect framework involves three main disadvantages. First, within the fixed effects framework it is not possible to estimate the impact of time-invariant factors that may be of interest such as regional locations of the MFIs, MFI type, and countrywide variables, such as Ceilings. Second, in the fixed effects framework, slowly changing values of the explanatory variables can result in imprecise coefficient estimates (Beck 2001). Third, the use of the fixed effects framework results in a loss of efficiency (relative to alternative assumptions on the nature of unobserved heterogeneity) as these models overlook variations across individuals (Baltagi 2005). Since the choice between the fixed and random effects frameworks in our context is not straightforward, and for comparability, we report estimates from both frameworks. We also report cluster robust (at the institution level) Huber/White standard errors for all estimates.

In response to this all or nothing choice of correlation between the individual effects and the regressors, Hausman-Taylor (1981) proposed an estimator where some of the regressors are correlated with the individual effects. The estimator is based on an instrumental variable estimator that uses both the between and within variation of the strictly exogenous regressors as instruments. The Hausman-Taylor estimator allows for possible correlation of some of the regressors with the unobserved effects and provides consistent parameter estimates of the time-varying variables. It forms its own set of instruments with internal variables and assumes four categories of explanatory variables: exogenous and endogenous time-varying regressors and exogenous and endogenous time-invariant regressors. In order to deploy the Hausman-Taylor estimator, one has to first distinguish between the endogenous variables (variables correlated with the unobserved individual effects) and the exogenous variables (variables not correlated with the unobserved individual effects). Identification requires that the number of exogenous time-variant variables is not less than the number of endogenous time-invariant variables and a sufficient correlation between the endogenous time-invariant variables and the instruments found in the process (Hartarska and Nadolnyak 2007). The endogenous variables are identified by finding the correlation between the explanatory variables and the unobserved individual effects at one per cent significance level. The validity of the internal instruments is assessed through the Sargan-Hansen test of overidentification. The analysis includes both univariate and multivariate models as a way to check for robustness. Table 4 shows the results of regressing interest rates on Trend, and the competition measures one at a time. Some researchers express concerns about data quality in evaluating the indicators of MFIs (Bauchet and Morduch 2010a, b; Mersland and Strøm 2010). To ensure that the results are not driven by quality and the availability of data, estimates for the interest rate model using data from MFIs with four and five diamonds are presented in Table 5. For 
Table 4 Univariate results

\begin{tabular}{|c|c|c|c|c|c|c|}
\hline & $\begin{array}{l}\text { (1) } \\
\text { FE }\end{array}$ & $\begin{array}{l}\text { (2) } \\
\mathrm{RE}\end{array}$ & $\begin{array}{l}\text { (3) } \\
\text { FE }\end{array}$ & $\begin{array}{l}(4) \\
\mathrm{RE}\end{array}$ & $\begin{array}{l}\text { (5) } \\
\text { FE }\end{array}$ & $\begin{array}{l}\text { (6) } \\
\mathrm{RE}\end{array}$ \\
\hline Trend & $\begin{array}{l}-0.00233 * * * \\
(0.000442)\end{array}$ & $\begin{array}{l}-0.00231 \text { *** } \\
(0.000432)\end{array}$ & $\begin{array}{l}-0.00259 * * * \\
(0.000465)\end{array}$ & $\begin{array}{l}-0.00243 * * * \\
(0.000452)\end{array}$ & $\begin{array}{l}-0.00215^{* * *} \\
(0.000304)\end{array}$ & $\begin{array}{l}-0.00220 * * * \\
(0.000298)\end{array}$ \\
\hline Office & $\begin{array}{l}0.0687 * * * \\
(0.0153)\end{array}$ & $\begin{array}{l}0.0618 * * * \\
(0.0137)\end{array}$ & & & & \\
\hline Herfindahl & & & $\begin{array}{l}0.0134 \\
(0.0119)\end{array}$ & $\begin{array}{l}0.0235^{* *} \\
(0.0102)\end{array}$ & & \\
\hline Lerner & & & & & $\begin{array}{l}0.0205 * * * \\
(0.00514)\end{array}$ & $\begin{array}{l}0.0275 * * * \\
(0.00514)\end{array}$ \\
\hline Constant & $\begin{array}{l}0.247 * * * \\
(0.00294)\end{array}$ & $\begin{array}{l}0.244 * * * \\
(0.00405)\end{array}$ & $\begin{array}{l}0.253 * * * \\
(0.00434)\end{array}$ & $\begin{array}{l}0.245 * * * \\
(0.00515)\end{array}$ & $\begin{array}{l}0.250^{* * *} \\
(0.00347)\end{array}$ & $\begin{array}{l}0.247 * * * \\
(0.00303)\end{array}$ \\
\hline$R$-squared & 0.0168 & 0.0167 & 0.0142 & 0.0140 & 0.0158 & 0.0153 \\
\hline MFIs & 1997 & 1997 & 1887 & 1887 & 1362 & 1362 \\
\hline$N$ & 9893 & 9893 & 8974 & 8974 & 6140 & 6140 \\
\hline
\end{tabular}

Standard errors in parentheses: $* p<0.10 ; * * p<0.05 ; * * * p<0.01$

comparability, Table 6 presents the estimates using only data from MFIs with one and three diamonds.

As indicated by Assefa et al. (2013), applying the concept of competition to all MFIs may render meaningless and unreliable results. To test if the profit status of an MFI makes a difference in its monopolistic behaviour, we divide the sample of the MFIs into for-profit and nonprofit according to their MIX Market classification. ${ }^{11}$

The estimates corresponding to for-profit MFIs are shown in Table 7, while Table 8 presents the results for nonprofit MFIs. Finally, using all available data, Table 9 shows the results of both the fixed and random effects models and Table 10 reports the results of the Hausman-Taylor model.

An additional remaining empirical issue is that the Lerner Index is a generated regressor. According to Pagan (1984) and Murphy and Topel (1985), while a two-step linear estimation method yields consistent estimates of the coefficients in the second stage regression, the standard errors will be inconsistent as they fail to account for the presence of a generated regressor. Consequently, statistical inferences can be biased in favour of rejecting the null hypothesis. To overcome this issue, we use bootstrapping method where we include both parts of the estimation for every bootstrap sample.

\footnotetext{
${ }^{11}$ In addition to using the MIX Market classification, we split the MFIs into different subsamples. First, we split the MFIs into a group that includes NGOs and cooperatives/credit unions, which are registered as nonprofit MFIs and a group that includes banks, nonbank financial institutions, and rural banks broadly defined to be for-profit MFIs. Second, in response to Cull et al. (2009) who argue that "Nonbank financial institutions are in a broad category that includes both for-profit and nonprofit," we split MFIs into two groups, the first group includes banks and rural banks and the other group includes nonbank financial institutions only. The monopolistic behaviour of the MFIs was consistent across all these subsamples.
} 


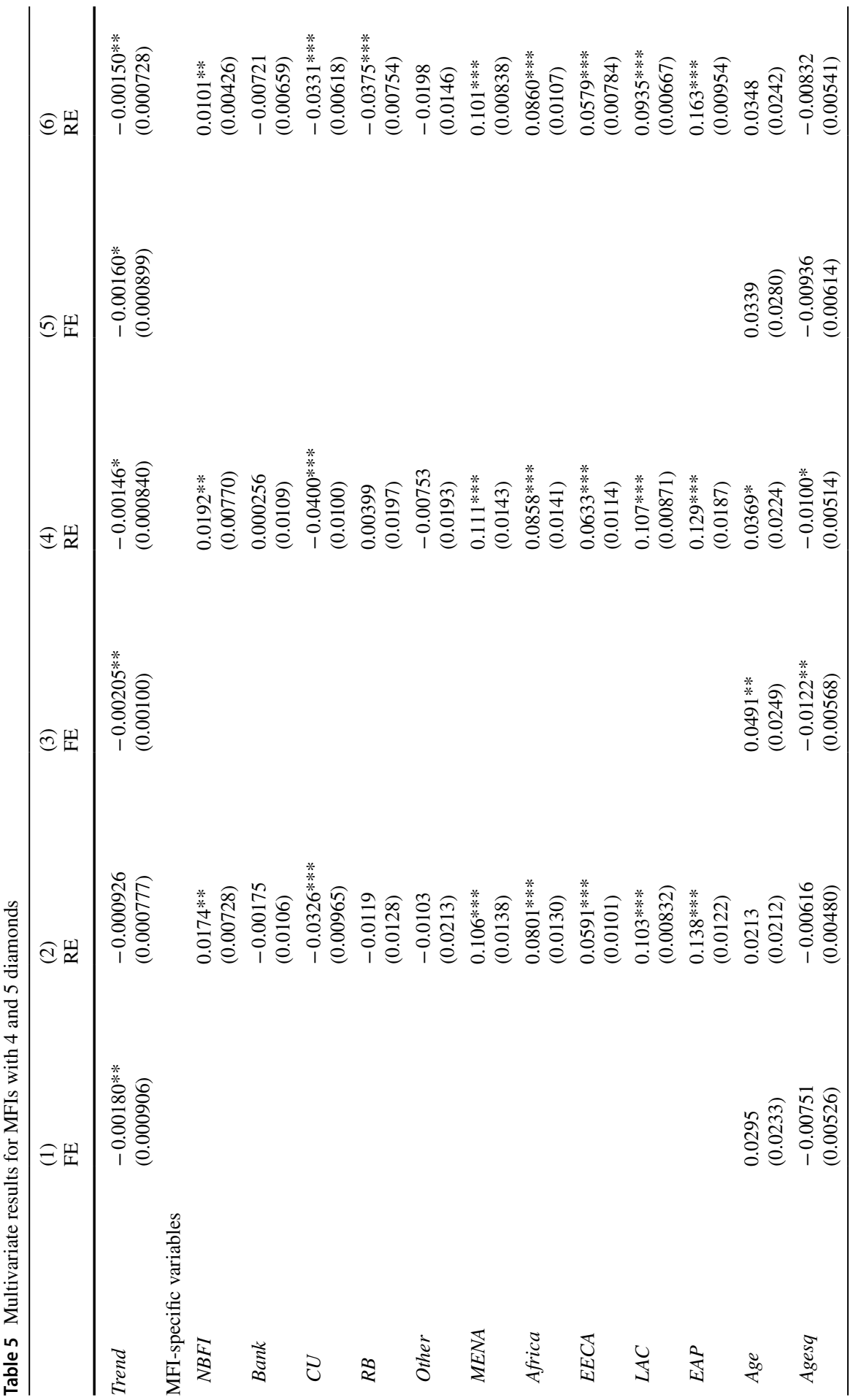

\section{글 Springer}




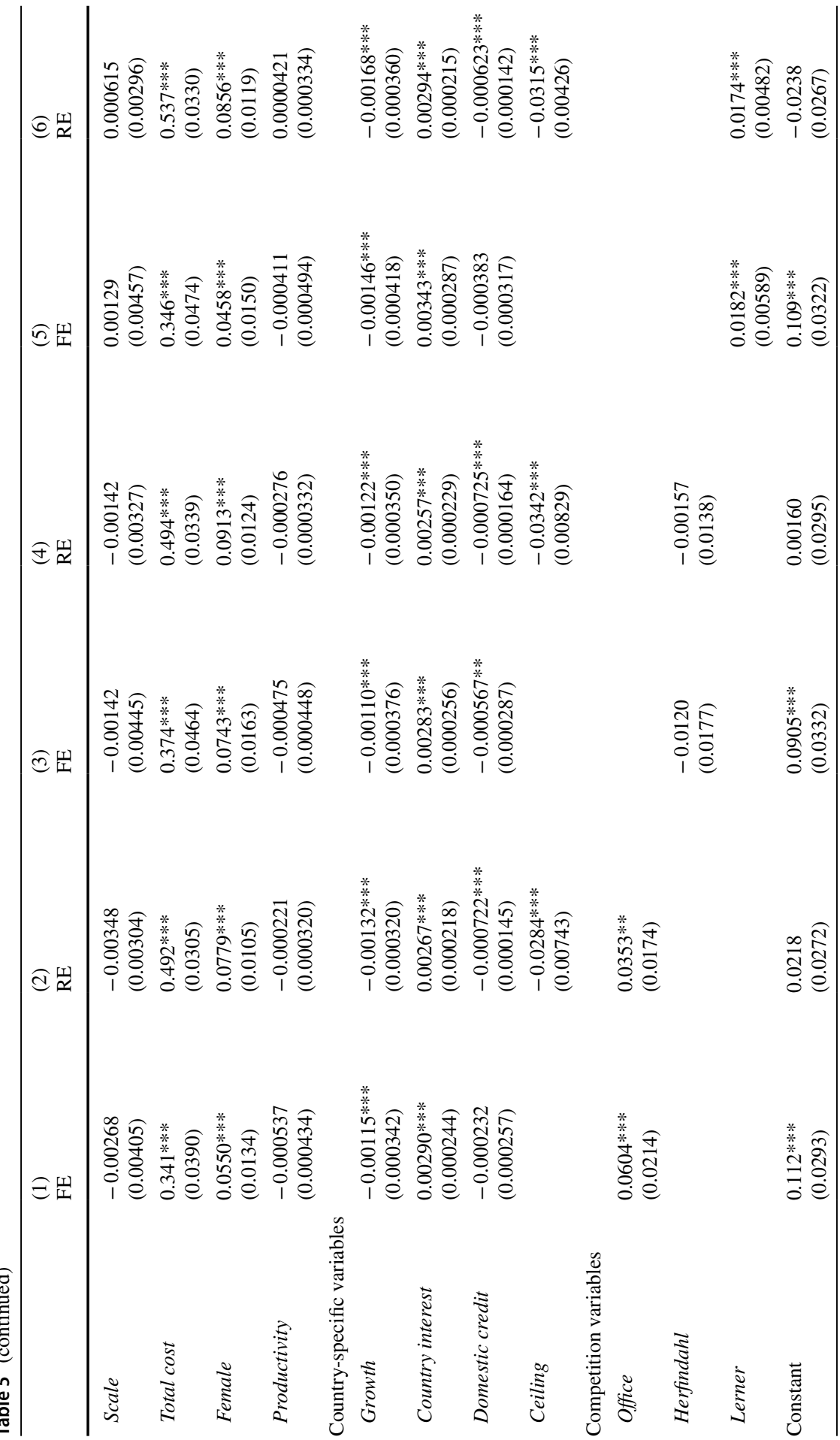




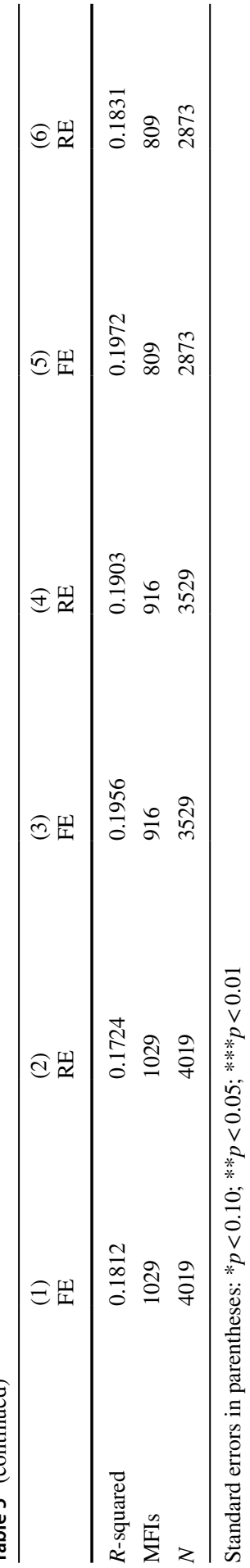


Table 6 Multivariate results for MFIs with less than 4 diamonds

\begin{tabular}{|c|c|c|c|c|c|c|}
\hline & $\begin{array}{l}(1) \\
\text { FE }\end{array}$ & $\begin{array}{l}(2) \\
\mathrm{RE}\end{array}$ & $\begin{array}{l}\text { (3) } \\
\text { FE }\end{array}$ & $\begin{array}{l}(4) \\
\mathrm{RE}\end{array}$ & $\begin{array}{l}(5) \\
\mathrm{FE}\end{array}$ & $\begin{array}{l}\text { (6) } \\
\mathrm{RE}\end{array}$ \\
\hline Trend & $\begin{array}{l}0.00366 * * \\
(0.00176)\end{array}$ & $\begin{array}{l}0.00513 * * * \\
(0.00152)\end{array}$ & $\begin{array}{l}0.00450 * * \\
(0.00195)\end{array}$ & $\begin{array}{l}0.00657 * * * \\
(0.00162)\end{array}$ & $\begin{array}{l}0.00449 * * \\
(0.00213)\end{array}$ & $\begin{array}{l}0.00495^{* * *} * \\
(0.00167)\end{array}$ \\
\hline \multicolumn{7}{|c|}{ MFI-specific variables } \\
\hline \multicolumn{2}{|l|}{$N B F I$} & $\begin{array}{l}0.0277 * * * \\
(0.00838)\end{array}$ & & $\begin{array}{l}0.0260 * * * \\
(0.00848)\end{array}$ & & $\begin{array}{l}0.0229 * * * \\
(0.00594)\end{array}$ \\
\hline \multicolumn{2}{|l|}{ Bank } & $\begin{array}{l}0.0315^{* * *} \\
(0.0127)\end{array}$ & & $\begin{array}{l}0.0339 * * \\
(0.0136)\end{array}$ & & $\begin{array}{l}0.0275 * * * \\
(0.00924)\end{array}$ \\
\hline \multicolumn{2}{|l|}{$C U$} & $\begin{array}{l}-0.0349 * * * \\
(0.00999)\end{array}$ & & $\begin{array}{l}-0.0318^{* * *} \\
(0.0101)\end{array}$ & & $\begin{array}{l}-0.0354 * * * \\
(0.00819)\end{array}$ \\
\hline \multicolumn{2}{|l|}{$R B$} & $\begin{array}{l}-0.0285 \\
(0.0184)\end{array}$ & & $\begin{array}{l}-0.0459 * * \\
(0.0197)\end{array}$ & & $\begin{array}{l}-0.0328 * * \\
(0.0144)\end{array}$ \\
\hline \multicolumn{2}{|l|}{ Other } & $\begin{array}{l}0.0290 \\
(0.0197)\end{array}$ & & $\begin{array}{l}0.0439 * * \\
(0.0180)\end{array}$ & & $\begin{array}{l}0.00632 \\
(0.00976)\end{array}$ \\
\hline \multicolumn{2}{|l|}{ MENA } & $\begin{array}{l}0.0966^{* * * *} \\
(0.0174)\end{array}$ & & $\begin{array}{l}0.0881 * * * \\
(0.0178)\end{array}$ & & $\begin{array}{l}0.0862 * * * \\
(0.0161)\end{array}$ \\
\hline \multicolumn{2}{|l|}{ Africa } & $\begin{array}{l}0.0752 * * * \\
(0.0135)\end{array}$ & & $\begin{array}{l}0.0684 * * * \\
(0.0145)\end{array}$ & & $\begin{array}{l}0.0938 * * * \\
(0.0107)\end{array}$ \\
\hline \multicolumn{2}{|l|}{$E E C A$} & $\begin{array}{l}0.0502 * * * \\
(0.0135)\end{array}$ & & $\begin{array}{l}0.0404 * * * \\
(0.0136)\end{array}$ & & $\begin{array}{l}0.0702 * * * \\
(0.0103)\end{array}$ \\
\hline \multicolumn{2}{|l|}{$L A C$} & $\begin{array}{l}0.118 * * * \\
(0.0107)\end{array}$ & & $\begin{array}{l}0.119 * * * \\
(0.0107)\end{array}$ & & $\begin{array}{l}0.120 * * * \\
(0.00914)\end{array}$ \\
\hline \multicolumn{2}{|l|}{$E A P$} & $\begin{array}{l}0.135^{* * * *} \\
(0.0151)\end{array}$ & & $\begin{array}{l}0.144 * * * \\
(0.0164)\end{array}$ & & $\begin{array}{l}0.161 * * * \\
(0.0105)\end{array}$ \\
\hline Age & $\begin{array}{l}0.0660 * * \\
(0.0327)\end{array}$ & $\begin{array}{l}0.0703 * * \\
(0.0306)\end{array}$ & $\begin{array}{l}-0.0378 \\
(0.0369)\end{array}$ & $\begin{array}{l}0.0141 \\
(0.0343)\end{array}$ & $\begin{array}{l}0.0257 \\
(0.0508)\end{array}$ & $\begin{array}{l}0.0461 \\
(0.0413)\end{array}$ \\
\hline Agesq & $\begin{array}{l}-0.0131 * \\
(0.00751)\end{array}$ & $\begin{array}{l}-0.0151^{* *} \\
(0.00706)\end{array}$ & $\begin{array}{l}0.00950 \\
(0.00812)\end{array}$ & $\begin{array}{l}-0.00259 \\
(0.00765)\end{array}$ & $\begin{array}{l}-0.00538 \\
(0.0108)\end{array}$ & $\begin{array}{l}-0.0101 \\
(0.00910)\end{array}$ \\
\hline Scale & $\begin{array}{l}-0.00859 \\
(0.00797)\end{array}$ & $\begin{array}{l}-0.00383 \\
(0.00405)\end{array}$ & $\begin{array}{l}-0.000884 \\
(0.00774)\end{array}$ & $\begin{array}{l}-0.00128 \\
(0.00385)\end{array}$ & $\begin{array}{l}-0.0146 \\
(0.00935)\end{array}$ & $\begin{array}{l}-0.00746 \\
(0.00468)\end{array}$ \\
\hline Total cost & $\begin{array}{l}0.261 * * * \\
(0.0681)\end{array}$ & $\begin{array}{l}0.494 * * * \\
(0.0411)\end{array}$ & $\begin{array}{l}0.212 * * * \\
(0.0717)\end{array}$ & $\begin{array}{l}0.486 * * * \\
(0.0432)\end{array}$ & $\begin{array}{l}0.297 * * * \\
(0.0830)\end{array}$ & $\begin{array}{l}0.522 * * * \\
(0.0531)\end{array}$ \\
\hline Female & $\begin{array}{l}0.0602 * * * \\
(0.0206)\end{array}$ & $\begin{array}{l}0.0972 * * * \\
(0.0141)\end{array}$ & $\begin{array}{l}0.0379 * * \\
(0.0189)\end{array}$ & $\begin{array}{l}0.0818 * * * \\
(0.0136)\end{array}$ & $\begin{array}{l}0.0810^{* *} \\
(0.0380)\end{array}$ & $\begin{array}{l}0.0928 * * * \\
(0.0181)\end{array}$ \\
\hline $\begin{array}{c}\text { Produc- } \\
\text { tivity }\end{array}$ & $\begin{array}{l}-0.00126^{* * *} \\
(0.000637)\end{array}$ & $\begin{array}{l}-0.000967 * * \\
(0.000431)\end{array}$ & $\begin{array}{l}-0.00148^{* *} \\
(0.000695)\end{array}$ & $\begin{array}{l}-0.000991 * * \\
(0.000462)\end{array}$ & $\begin{array}{l}-0.000847 \\
(0.000682)\end{array}$ & $\begin{array}{l}-0.00114^{* *} \\
(0.000480)\end{array}$ \\
\hline \multicolumn{7}{|c|}{ Country-specific variables } \\
\hline Growth & $\begin{array}{l}-0.000405 \\
(0.000546)\end{array}$ & $\begin{array}{l}-0.000912^{*} \\
(0.000534)\end{array}$ & $\begin{array}{l}-0.000443 \\
(0.000544)\end{array}$ & $\begin{array}{l}-0.00118 * * \\
(0.000552)\end{array}$ & $\begin{array}{l}-0.000177 \\
(0.000826)\end{array}$ & $\begin{array}{l}-0.00120^{* *} \\
(0.000599)\end{array}$ \\
\hline $\begin{array}{c}\text { Country } \\
\text { interest }\end{array}$ & $\begin{array}{l}0.00164 * * * \\
(0.000487)\end{array}$ & $\begin{array}{l}0.000907 * * \\
(0.000374)\end{array}$ & $\begin{array}{l}0.00187 * * * \\
(0.000519)\end{array}$ & $\begin{array}{l}0.000620 \\
(0.000401)\end{array}$ & $\begin{array}{l}0.00122 \\
(0.000766)\end{array}$ & $\begin{array}{l}0.0000260 \\
(0.000403)\end{array}$ \\
\hline $\begin{array}{l}\text { Domestic } \\
\text { credit }\end{array}$ & $\begin{array}{l}-0.00130 * * \\
(0.000542)\end{array}$ & $\begin{array}{l}-0.00134 * * * \\
(0.000204)\end{array}$ & $\begin{array}{l}-0.00127 * * * \\
(0.000429)\end{array}$ & $\begin{array}{l}-0.00142 * * * \\
(0.000181)\end{array}$ & $\begin{array}{l}-0.00200 * * * \\
(0.000755)\end{array}$ & $\begin{array}{l}-0.00156^{* * * *} \\
(0.000230)\end{array}$ \\
\hline Ceiling & & $\begin{array}{l}-0.0273 * * * \\
(0.00996)\end{array}$ & & $\begin{array}{l}-0.0325^{* * *} \\
(0.00943)\end{array}$ & & $\begin{array}{l}-0.0160 * * \\
(0.00648)\end{array}$ \\
\hline \multicolumn{7}{|c|}{ Competition variables } \\
\hline Office & $\begin{array}{l}0.00614 \\
(0.0328)\end{array}$ & $\begin{array}{l}0.0166 \\
(0.0201)\end{array}$ & & & & \\
\hline \multicolumn{2}{|l|}{$\begin{array}{l}\text { Herfind- } \\
\text { ahl }\end{array}$} & & $\begin{array}{l}-0.00467 \\
(0.0187)\end{array}$ & $\begin{array}{l}-0.0111 \\
(0.0155)\end{array}$ & & \\
\hline
\end{tabular}


Table 6 (continued)

\begin{tabular}{lllllll}
\hline & $(1)$ & $(2)$ & $(3)$ & $(4)$ & $(5)$ & $(6)$ \\
& FE & RE & FE & RE & FE & RE \\
\hline Lerner & & & & & 0.0192 & $0.0200^{*}$ \\
& & & & $0.0122)$ & $(0.0111)$ \\
Constant & $0.127 * * *$ & -0.0285 & $0.246^{* * *}$ & 0.0477 & $0.185^{* * *}$ & 0.00909 \\
& $(0.0465)$ & $(0.0375)$ & $(0.0618)$ & $(0.0445)$ & $(0.0695)$ & $(0.0460)$ \\
$R$-squared & 0.1200 & 0.1041 & 0.1069 & 0.0800 & 0.1554 & 0.1316 \\
MFIs & 949 & 949 & 879 & 879 & 663 & 663 \\
$N$ & 2152 & 2152 & 1830 & 1830 & 1334 & 1334 \\
\hline
\end{tabular}

Standard errors in parentheses: $* p<0.10 ; * * p<0.05 ; * * * p<0.01$

In addition to dropping the lowest and highest $2.5 \%$ of the values of each variable used (to mitigate the impact of outliers) several other robustness checks were undertaken: converting the unbalanced data to a balanced panel and the use of median and robust regressions. Each of these exercises yielded similar results to those obtained from our baseline estimates. These results are not presented here but are available upon request.

\section{Results and discussion}

The estimates pertaining to the MFI and country-specific control variables are first briefly discussed. Our estimates for these variables are, in general, in line with the extant literature. The overall results for Trend, and in conjunction with Fig. 1, suggest that the evolution of interest rates over time are not stable and that interest rates vary by both MFI type and region. ${ }^{12}$ In general, the results show an inverted U-shaped relationship between Age and interest rates, and they show that larger MFIs, as measured by Scale, tend to charge lower interest rates. The impacts of Age and Scale are most evident in the full samples. On average, female borrowers are charged higher interest rates relative to male borrowers. As expected, the estimates show that total cost is a strong predictor of interest rates in all subsamples. In addition, the overall estimates indicate that MFIs with more productive staff members provide microcredit at lower interest rates. The impact of the macroeconomic environment on microcredit interest rates is also evident. The lagged growth of the domestic economy is negatively related to interest rates. Higher economic growth may allow MFIs to better access less costly funds and, at the same time, may reduce household demand for microcredit, as they substitute away to commercial banks, both of which reduce interest rates. The results also suggest that microcredit interest rates move tightly with the home country lending interest rates. In addition, a more developed financial sector, measured by domestic credit to private sector, seems to

\footnotetext{
12 While the results in Tables 4 and 5 suggest that interest rates are falling over time, the results from the rest of the tables reveal different trends.
} 
Table 7 Multivariate results for for-profit MFIs

\begin{tabular}{|c|c|c|c|c|c|c|}
\hline & $\begin{array}{l}(1) \\
\text { FE }\end{array}$ & $\begin{array}{l}(2) \\
\mathrm{RE}\end{array}$ & $\begin{array}{l}(3) \\
\text { FE }\end{array}$ & $\begin{array}{l}(4) \\
\mathrm{RE}\end{array}$ & $\begin{array}{l}\text { (5) } \\
\text { FE }\end{array}$ & $\begin{array}{l}(6) \\
\mathrm{RE}\end{array}$ \\
\hline Trend & $\begin{array}{l}-0.000135 \\
(0.00104)\end{array}$ & $\begin{array}{l}0.000614 \\
(0.000920)\end{array}$ & $\begin{array}{l}0.000339 \\
(0.00114)\end{array}$ & $\begin{array}{l}0.00102 \\
(0.000976)\end{array}$ & $\begin{array}{l}0.000611 \\
(0.000842)\end{array}$ & $\begin{array}{l}0.00154 * * \\
(0.000722)\end{array}$ \\
\hline \multicolumn{7}{|c|}{ MFI-specific variables } \\
\hline \multicolumn{2}{|l|}{$N B F I$} & \multicolumn{2}{|l|}{$\begin{array}{l}-0.0138 \\
(0.0361)\end{array}$} & \multicolumn{2}{|l|}{$\begin{array}{l}0.0124 \\
(0.0256)\end{array}$} & 0.000531 \\
\hline \multicolumn{2}{|l|}{ Bank } & \multicolumn{2}{|l|}{$\begin{array}{l}-0.0353 \\
(0.0382)\end{array}$} & \multicolumn{2}{|l|}{$\begin{array}{l}-0.00636 \\
(0.0283)\end{array}$} & $\begin{array}{l}-0.0178 \\
(0.0200)\end{array}$ \\
\hline \multicolumn{2}{|l|}{$C U$} & \multicolumn{2}{|l|}{$\begin{array}{l}-0.0650^{*} \\
(0.0366)\end{array}$} & \multicolumn{2}{|l|}{$\begin{array}{l}-0.0332 \\
(0.0285)\end{array}$} & $\begin{array}{l}-0.0561 * * \\
(0.0246)\end{array}$ \\
\hline \multicolumn{2}{|l|}{$R B$} & \multicolumn{2}{|l|}{$\begin{array}{l}-0.0460 \\
(0.0384)\end{array}$} & \multicolumn{2}{|l|}{$\begin{array}{l}-0.0325 \\
(0.0308)\end{array}$} & $\begin{array}{l}-0.0508^{* * *} \\
(0.0189)\end{array}$ \\
\hline \multicolumn{2}{|l|}{ Other } & \multicolumn{2}{|l|}{$\begin{array}{l}-0.0203 \\
(0.0467)\end{array}$} & \multicolumn{2}{|l|}{$\begin{array}{l}0.00773 \\
(0.0398)\end{array}$} & $\begin{array}{l}-0.0267 \\
(0.0303)\end{array}$ \\
\hline \multicolumn{2}{|l|}{ MENA } & \multicolumn{2}{|l|}{$\begin{array}{l}0.0134 \\
(0.0297)\end{array}$} & \multicolumn{2}{|l|}{$\begin{array}{l}-0.0318 \\
(0.0281)\end{array}$} & $\begin{array}{l}0.0216 \\
(0.0160)\end{array}$ \\
\hline \multicolumn{2}{|l|}{ Africa } & \multicolumn{2}{|l|}{$\begin{array}{l}0.0862 * * * \\
(0.0191)\end{array}$} & \multicolumn{2}{|l|}{$\begin{array}{l}0.0555^{* *} \\
(0.0226)\end{array}$} & $\begin{array}{l}0.0788^{* * *} \\
(0.0119)\end{array}$ \\
\hline \multicolumn{2}{|l|}{$E E C A$} & \multicolumn{2}{|l|}{$\begin{array}{l}0.0469 * * * \\
(0.0155)\end{array}$} & \multicolumn{2}{|l|}{$\begin{array}{l}0.0183 \\
(0.0175)\end{array}$} & $\begin{array}{l}0.0345 * * * \\
(0.0113)\end{array}$ \\
\hline \multicolumn{2}{|l|}{$L A C$} & \multicolumn{2}{|l|}{$\begin{array}{l}0.131 * * * \\
(0.0135)\end{array}$} & \multicolumn{2}{|l|}{$\begin{array}{l}0.116 * * * \\
(0.0139)\end{array}$} & $\begin{array}{l}0.114 * * * \\
(0.00934)\end{array}$ \\
\hline \multicolumn{2}{|l|}{ EAP } & \multicolumn{2}{|l|}{$\begin{array}{l}0.127 * * * \\
(0.0184)\end{array}$} & \multicolumn{2}{|l|}{$\begin{array}{l}0.122 * * * \\
(0.0209)\end{array}$} & $\begin{array}{l}0.151 * * * \\
(0.0132)\end{array}$ \\
\hline Age & $\begin{array}{l}-0.00496 \\
(0.0242)\end{array}$ & $\begin{array}{l}0.00639 \\
(0.0224)\end{array}$ & $\begin{array}{l}0.000757 \\
(0.0223)\end{array}$ & $\begin{array}{l}0.0120 \\
(0.0207)\end{array}$ & $\begin{array}{l}-0.00870 \\
(0.0215)\end{array}$ & $\begin{array}{l}0.00636 \\
(0.0202)\end{array}$ \\
\hline Agesq & $\begin{array}{l}0.00269 \\
(0.00556)\end{array}$ & $\begin{array}{c}-0.00103 \\
(0.00518)\end{array}$ & $\begin{array}{l}0.00144 \\
(0.00511)\end{array}$ & $\begin{array}{l}-0.00219 \\
(0.00479)\end{array}$ & $\begin{array}{l}0.00214 \\
(0.00468)\end{array}$ & $\begin{array}{l}-0.00135 \\
(0.00448)\end{array}$ \\
\hline Scale & $\begin{array}{l}0.000972 \\
(0.00523)\end{array}$ & $\begin{array}{l}-0.00591 \\
(0.00419)\end{array}$ & $\begin{array}{l}0.00272 \\
(0.00556)\end{array}$ & $\begin{array}{l}-0.00313 \\
(0.00438)\end{array}$ & $\begin{array}{l}0.00175 \\
(0.00483)\end{array}$ & $\begin{array}{l}-0.00517 \\
(0.00392)\end{array}$ \\
\hline Total cost & $\begin{array}{l}0.397 * * * \\
(0.0526)\end{array}$ & $\begin{array}{l}0.525 * * * \\
(0.0407)\end{array}$ & $\begin{array}{l}0.388 * * * \\
(0.0548)\end{array}$ & $\begin{array}{l}0.514 * * * \\
(0.0442)\end{array}$ & $\begin{array}{l}0.350 * * * \\
(0.0480)\end{array}$ & $\begin{array}{l}0.538 * * * \\
(0.0385)\end{array}$ \\
\hline Female & $\begin{array}{l}0.0623 * * * \\
(0.0219)\end{array}$ & $\begin{array}{l}0.0918^{* * *} * \\
(0.0155)\end{array}$ & $\begin{array}{l}0.0712 * * * \\
(0.0222)\end{array}$ & $\begin{array}{l}0.0970 * * * \\
(0.0166)\end{array}$ & $\begin{array}{l}0.0499 \text { *** } \\
(0.0180)\end{array}$ & $\begin{array}{l}0.0918 * * * \\
(0.0116)\end{array}$ \\
\hline $\begin{array}{c}\text { Produc- } \\
\text { tivity }\end{array}$ & $\begin{array}{l}-0.000595 \\
(0.000531)\end{array}$ & $\begin{array}{l}-0.000497 \\
(0.000435)\end{array}$ & $\begin{array}{l}-0.000667 \\
(0.000528)\end{array}$ & $\begin{array}{l}-0.000588 \\
(0.000444)\end{array}$ & $\begin{array}{l}-0.000760 \\
(0.000511)\end{array}$ & $\begin{array}{l}-0.000454 \\
(0.000424)\end{array}$ \\
\hline \multicolumn{7}{|c|}{ Country-specific variables } \\
\hline Growth & $\begin{array}{l}-0.000646^{*} \\
(0.000365)\end{array}$ & $\begin{array}{l}-0.000888 * * \\
(0.000359)\end{array}$ & $\begin{array}{l}-0.000287 \\
(0.000407)\end{array}$ & $\begin{array}{l}-0.000421 \\
(0.000406)\end{array}$ & $\begin{array}{l}-0.000894 * * \\
(0.000446)\end{array}$ & $\begin{array}{l}-0.00140 * * * \\
(0.000442)\end{array}$ \\
\hline $\begin{array}{l}\text { Country } \\
\text { interest }\end{array}$ & $\begin{array}{l}0.00231^{* * * *} \\
(0.000324)\end{array}$ & $\begin{array}{l}0.00162 * * * \\
(0.000313)\end{array}$ & $\begin{array}{l}0.00253^{* * *} * \\
(0.000321)\end{array}$ & $\begin{array}{l}0.00184 * * * \\
(0.000317)\end{array}$ & $\begin{array}{l}0.00293 * * * \\
(0.000370)\end{array}$ & $\begin{array}{l}0.00207 * * * \\
(0.000294)\end{array}$ \\
\hline $\begin{array}{l}\text { Domestic } \\
\text { credit }\end{array}$ & $\begin{array}{l}-0.00150 * * * \\
(0.000365)\end{array}$ & $\begin{array}{l}-0.00113 * * * \\
(0.000240)\end{array}$ & $\begin{array}{l}-0.00178 * * * \\
(0.000407)\end{array}$ & $\begin{array}{l}-0.00148 * * * \\
(0.000270)\end{array}$ & $\begin{array}{l}-0.00104 * * * \\
(0.000286)\end{array}$ & $\begin{array}{l}-0.000930 * * * \\
(0.000182)\end{array}$ \\
\hline Ceiling & & $\begin{array}{l}-0.0349 * * * \\
(0.0101)\end{array}$ & & $\begin{array}{l}-0.0474 * * * \\
(0.0104)\end{array}$ & & $\begin{array}{l}-0.0513 \text { *** } \\
(0.00504)\end{array}$ \\
\hline Competition & variables & & & & & \\
\hline Office & $\begin{array}{l}0.0697 * * * \\
(0.0249)\end{array}$ & $\begin{array}{l}0.0436 * * \\
(0.0202)\end{array}$ & & & & \\
\hline $\begin{array}{l}\text { Herfind- } \\
\text { ahl }\end{array}$ & & & $\begin{array}{l}0.0657 * * * \\
(0.0230)\end{array}$ & $\begin{array}{l}0.0533 * * * \\
(0.0179)\end{array}$ & & \\
\hline
\end{tabular}


Table 7 (continued)

\begin{tabular}{lllllll}
\hline & $(1)$ & $(2)$ & $(3)$ & $(4)$ & $(5)$ & $(6)$ \\
& FE & RE & FE & RE & FE & RE \\
\hline Lerner & & & & & $0.0144 * *$ & $0.0114^{*}$ \\
& & & & $(0.00721)$ & $(0.00600)$ \\
Constant & $0.147^{* * *}$ & 0.0695 & $0.122^{* * *}$ & 0.0450 & $0.158^{* * *}$ & 0.0524 \\
& $(0.0351)$ & $(0.0481)$ & $(0.0365)$ & $(0.0407)$ & $(0.0391)$ & $(0.0390)$ \\
$R$-squared & 0.1936 & 0.1802 & 0.1882 & 0.1760 & 0.1846 & 0.1653 \\
MFIs & 558 & 558 & 534 & 534 & 435 & 435 \\
$N$ & 2582 & 2582 & 2365 & 2365 & 1820 & 1820 \\
\hline
\end{tabular}

Standard errors in parentheses: $* p<0.10 ; * * p<0.05 ; * * * p<0.01$

be a strong predictor of lower interest rates. Unsurprisingly, MFIs subject to interest rate ceilings appear to charge lower interest rates.

The overall impact of competition on interest rates is evident across all models, specifications, and subsamples. Broadly speaking, the results indicate that MFIs with more monopoly power charge higher interest rates.

The coefficients on Office are positive and statistically significant, suggesting that MFIs with a greater share of the total number of office branches charge higher interest rates. This relationship holds except for MFIs with a diamond rating between one and three (Table 6) where the impact, though positive (and economically significant), is statistically insignificant. MFIs usually expand in more marginalised areas where communities have little access to financial services. ${ }^{13}$ Such an expansion may allow these MFIs to gain additional monopoly power and charge higher interest rates. In addition, such an expansion may lead to more concentrated markets and the failure of some smaller MFIs, both of which increase interest rates.

The overall results for Herfindahl suggest, albeit weakly, that higher concentration in terms of gross loan portfolio tends to increase interest rates. The coefficient estimates on Herfindhal are positive and statistically significant in only 3 of the 12 specifications considered. This measure may not be a good proxy for competition, as it may fail to capture the geographical scope and market segmentation of the operating environment for MFIs in a given country. For example, each MFI may have a $10 \%$ market share, but may occupy 10 different areas in which they are monopoly providers with no actual competition against each other. In addition, it does not account for the availability of close lending substitutes offered by moneylenders and commercial banks that may dilute the monopoly power of the MFIs.

In general, the first two measures of competition do not reflect the MFI-specific demand that determines an MFI's ability to raise prices and can be confronted for their ability and their use as measures of monopoly power. MFIs that set a price

\footnotetext{
13 The impact of competition based on office share can depend on the number of branches of commercial banks. More branches of commercial banks may reduce the monopoly power of the MFIs with more office shares. To address this point, we add the number of commercial bank branches per 100,000 people provided by the World Bank as a new independent variable and its interaction term with Office. The sign of the coefficient on the interaction term is negative but statistically insignificant.
} 


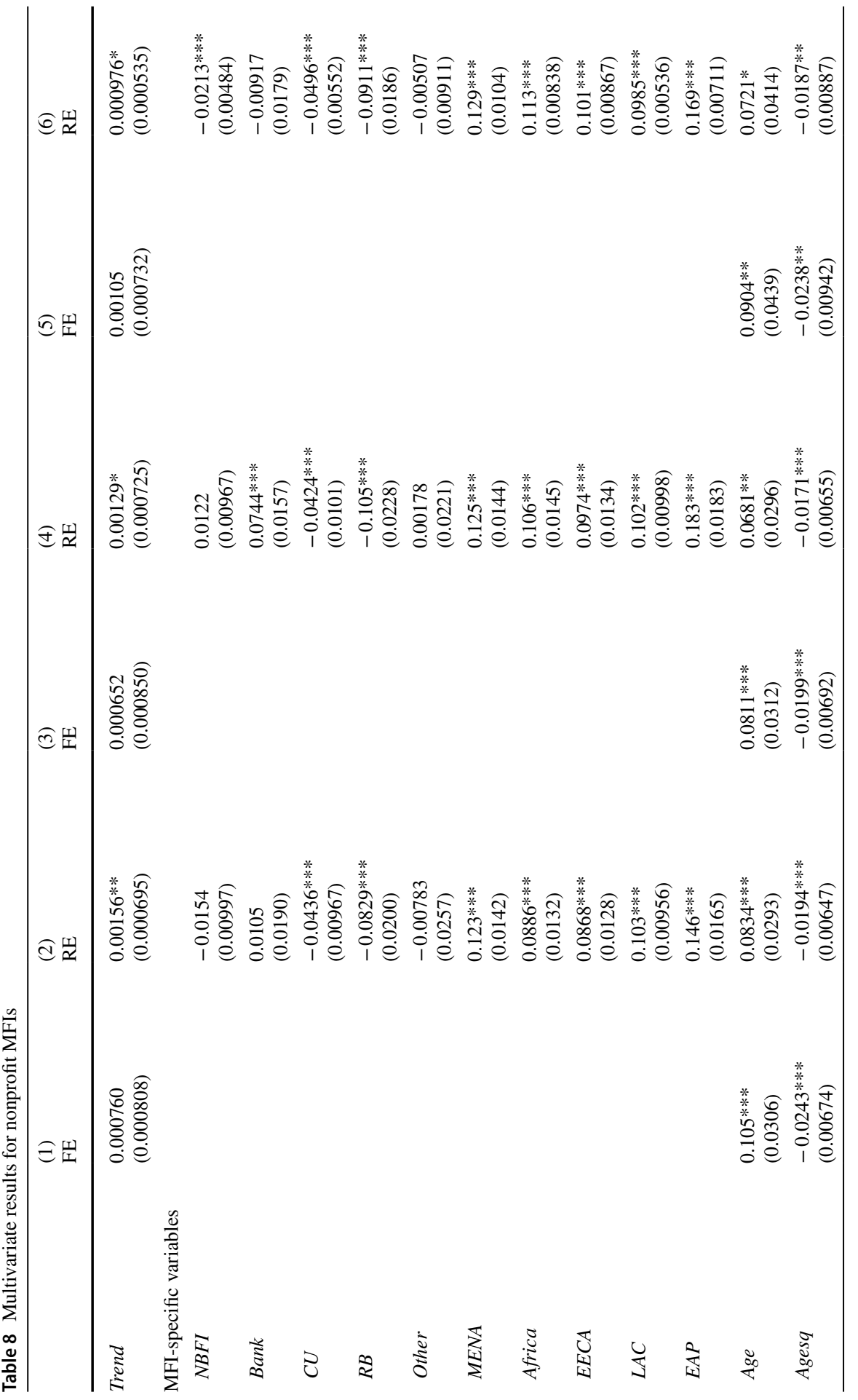




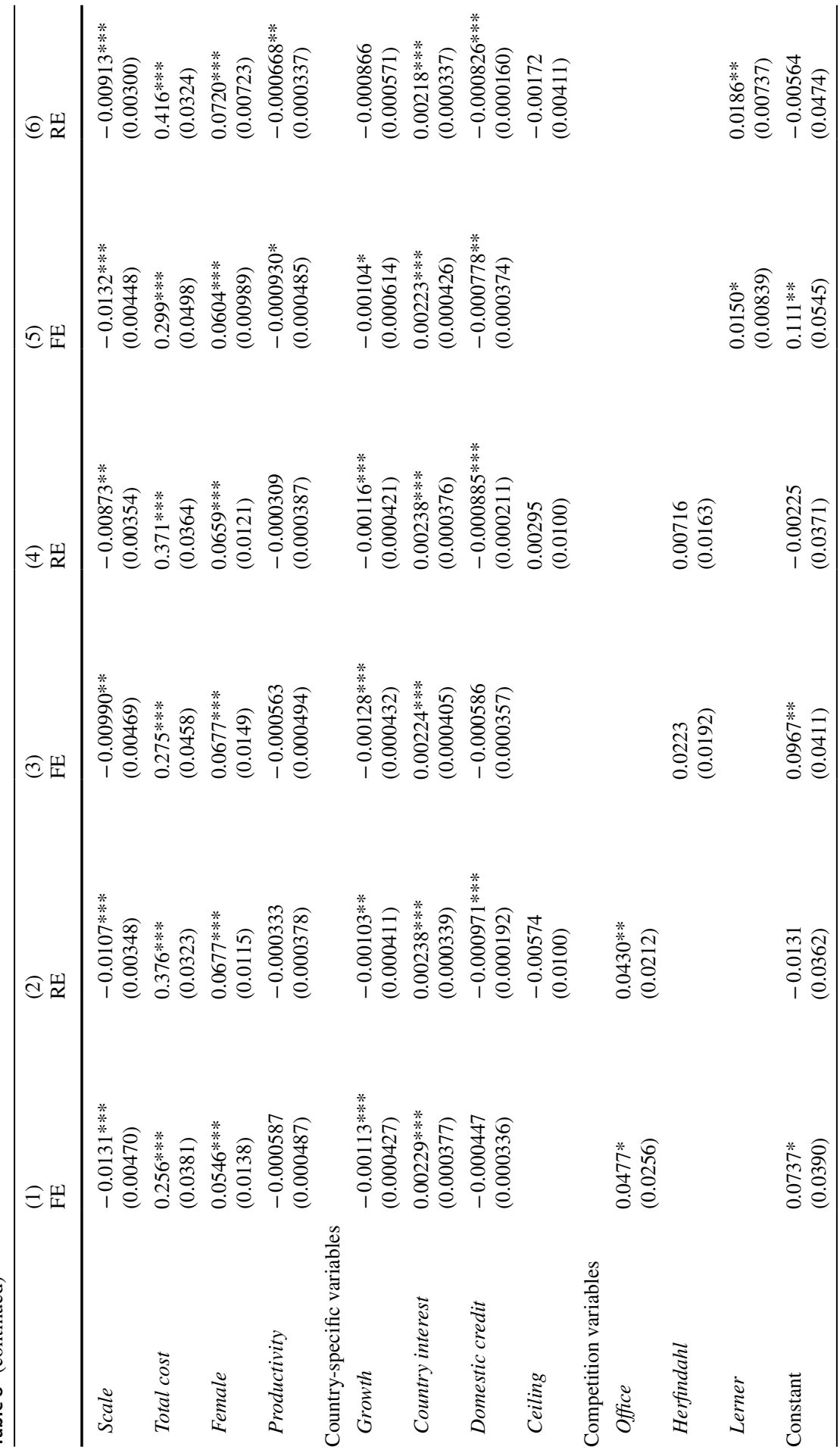




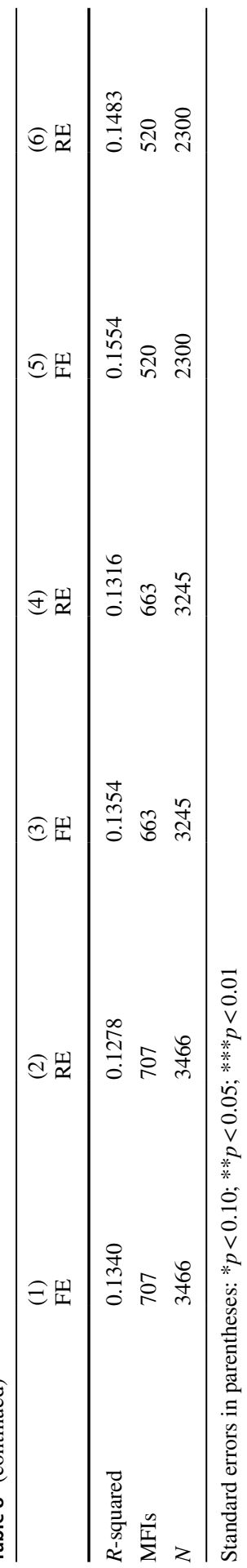




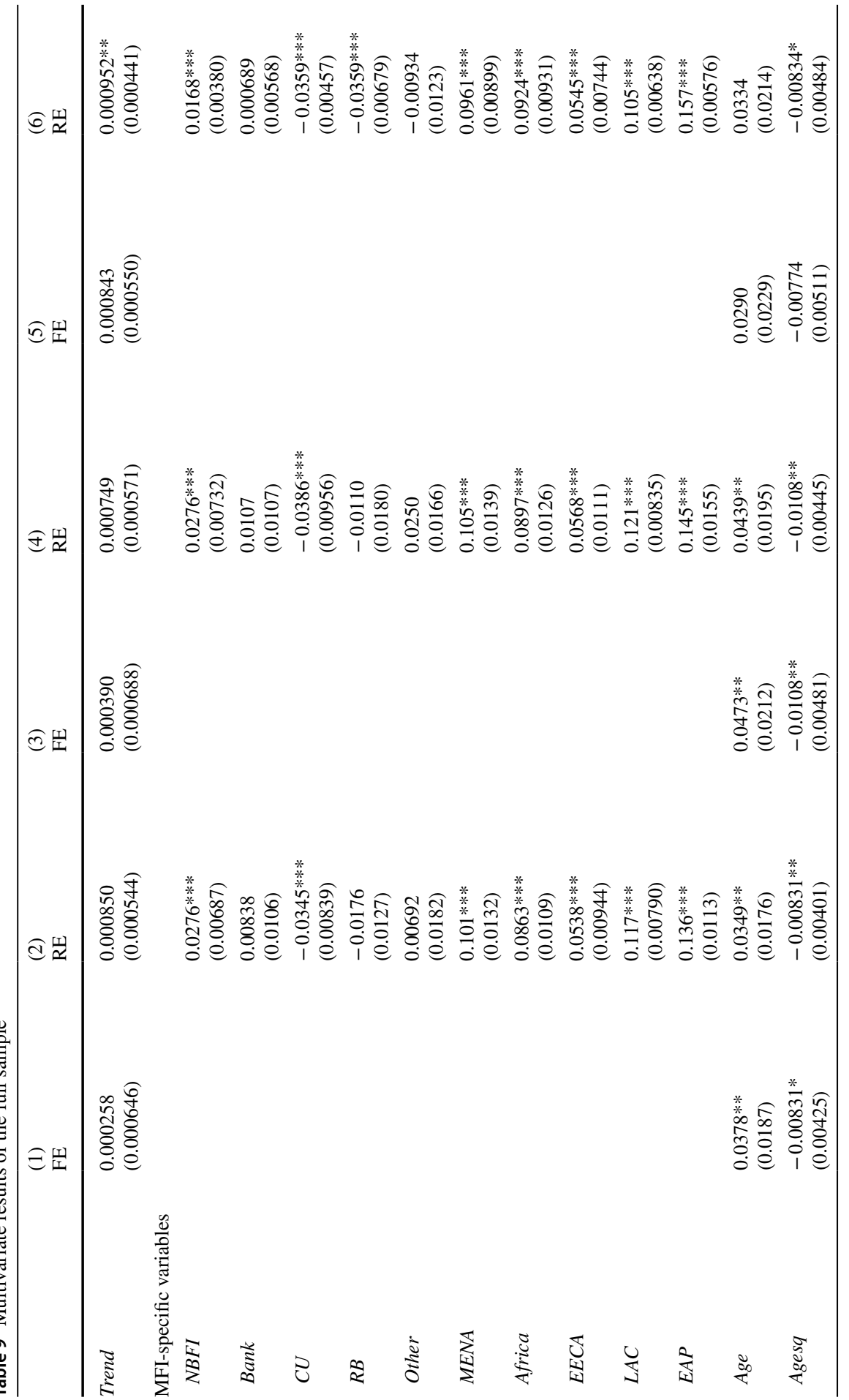




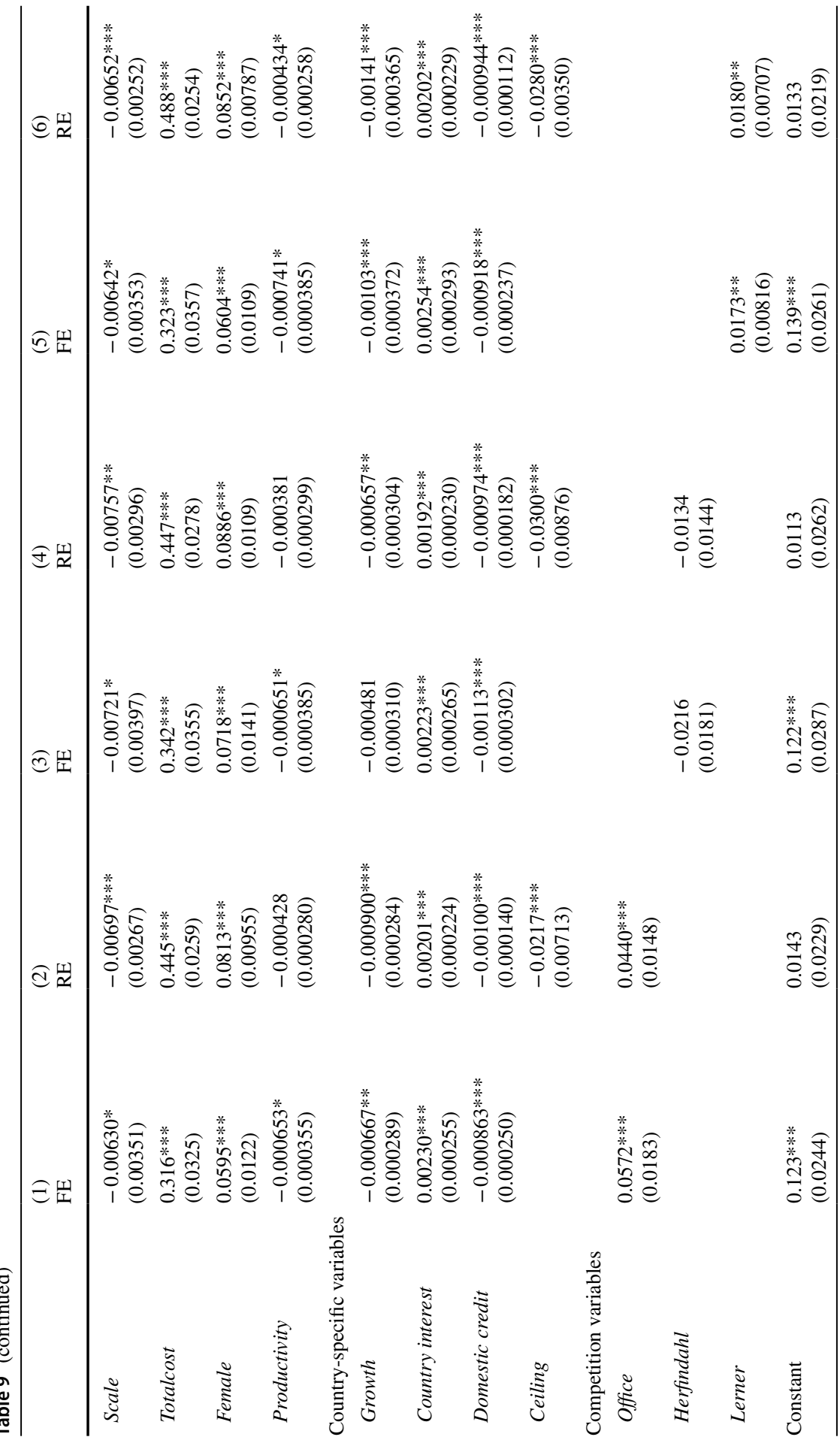




|


Table 10 Multivariate results of the full sample: Hausman-Taylor estimates

(1) (2) (3)

\begin{tabular}{|c|c|c|c|c|c|}
\hline \multicolumn{6}{|c|}{ Time-varying exogenous variables } \\
\hline Trend & $\begin{array}{l}0.000258 \\
(0.000406)\end{array}$ & Scale & $\begin{array}{l}-0.00721 * * * \\
(0.00263)\end{array}$ & Trend & $\begin{array}{l}0.00111 * * \\
(0.000435)\end{array}$ \\
\hline Scale & $\begin{array}{l}-0.00630 * * * \\
(0.00232)\end{array}$ & Productivity & $\begin{array}{l}-0.00651 * * \\
(0.00259)\end{array}$ & Age & $\begin{array}{l}0.0320 * * \\
(0.0136)\end{array}$ \\
\hline Productivity & $\begin{array}{l}-0.00653 * * * \\
(0.00226)\end{array}$ & Growth & $\begin{array}{l}-0.000481 * \\
(0.000270)\end{array}$ & Agesq & $\begin{array}{l}-0.00871^{* * *} \\
(0.00311)\end{array}$ \\
\hline \multirow[t]{4}{*}{ Growth } & $\begin{array}{l}-0.000667 * * * \\
(0.000249)\end{array}$ & Domestic credit & $\begin{array}{l}-0.00113 * * * \\
(0.000177)\end{array}$ & Scale & $\begin{array}{l}-0.00686^{* * * *} \\
(0.00244)\end{array}$ \\
\hline & & & & Productivity & $\begin{array}{l}-0.00648 * * \\
(0.00263)\end{array}$ \\
\hline & & & & Growth & $\begin{array}{l}-0.00105^{* * * *} \\
(0.000287)\end{array}$ \\
\hline & & & & Domestic credit & $\begin{array}{l}-0.000996^{* * * *} \\
(0.000154)\end{array}$ \\
\hline \multicolumn{6}{|c|}{ Time-varying endogenous variables } \\
\hline Age & $\begin{array}{l}0.0378 * * * \\
(0.0116)\end{array}$ & Trend & $\begin{array}{l}0.000390 \\
(0.000452)\end{array}$ & Total cost & $\begin{array}{l}0.331 * * * \\
(0.0193)\end{array}$ \\
\hline Agesq & $\begin{array}{l}-0.00831 * * * \\
(0.00268)\end{array}$ & Age & $\begin{array}{l}0.0473 * * * \\
(0.0134)\end{array}$ & Female & $\begin{array}{l}0.0615 * * * \\
(0.0102)\end{array}$ \\
\hline Total cost & $\begin{array}{l}0.316^{* * * *} \\
(0.0149)\end{array}$ & Agesq & $\begin{array}{l}-0.0108 * * * \\
(0.00308)\end{array}$ & Country interest & $\begin{array}{l}0.00253 * * * \\
(0.000184)\end{array}$ \\
\hline Female & $\begin{array}{l}0.0595 * * * \\
(0.00883)\end{array}$ & Total cost & $\begin{array}{l}0.342 * * * \\
(0.0167)\end{array}$ & Lerner & $0.00984 * * *$ \\
\hline $\begin{array}{l}\text { Country inter- } \\
\text { est }\end{array}$ & $\begin{array}{l}0.00230 * * * \\
(0.000159)\end{array}$ & Female & $\begin{array}{l}0.0718^{* * *} * \\
(0.00993)\end{array}$ & & \\
\hline $\begin{array}{l}\text { Domestic } \\
\text { credit }\end{array}$ & $\begin{array}{l}-0.000863^{* * * *} \\
(0.000152)\end{array}$ & Country interest & $\begin{array}{l}0.00223 * * * \\
(0.000170)\end{array}$ & & \\
\hline Office & $\begin{array}{l}0.0572 * * * \\
(0.0119)\end{array}$ & Herfindahl & $\begin{array}{l}-0.0206 \\
(0.0127)\end{array}$ & & \\
\hline \multicolumn{6}{|c|}{ Time-invariant exogenous variables } \\
\hline Bank & $\begin{array}{l}-0.0190 \\
(0.0262)\end{array}$ & $N B F I$ & $\begin{array}{l}0.0893 \\
(0.104)\end{array}$ & $N B F I$ & $\begin{array}{l}0.0152 \\
(0.0140)\end{array}$ \\
\hline$C U$ & $\begin{array}{l}-0.0826 * * * \\
(0.0246)\end{array}$ & Bank & $\begin{array}{l}0.0555 \\
(0.0880)\end{array}$ & Bank & $\begin{array}{l}-0.0101 \\
(0.0185)\end{array}$ \\
\hline$R B$ & $\begin{array}{l}-0.0636^{*} \\
(0.0348)\end{array}$ & $C U$ & $\begin{array}{l}-0.00458 \\
(0.0901)\end{array}$ & $C U$ & $\begin{array}{l}-0.0598 * * * \\
(0.0146)\end{array}$ \\
\hline Other & $\begin{array}{l}-0.00827 \\
(0.0399)\end{array}$ & $R B$ & $\begin{array}{l}0.00541 \\
(0.0637)\end{array}$ & $R B$ & $\begin{array}{l}-0.0354 \\
(0.0704)\end{array}$ \\
\hline MENA & $\begin{array}{l}0.0544 \\
(0.0496)\end{array}$ & MENA & $\begin{array}{l}0.0403 \\
(0.103)\end{array}$ & Other & $\begin{array}{l}0.00226 \\
(0.0303)\end{array}$ \\
\hline Africa & $\begin{array}{l}0.0577 \\
(0.0608)\end{array}$ & Africa & $\begin{array}{l}0.0680 \\
(0.0499)\end{array}$ & MENA & $\begin{array}{l}0.0848 * * * \\
(0.0274)\end{array}$ \\
\hline \multirow[t]{2}{*}{$E A P$} & $\begin{array}{l}0.134 * * * \\
(0.0225)\end{array}$ & $E A P$ & $\begin{array}{l}0.144 * * * \\
(0.0356)\end{array}$ & Africa & $\begin{array}{l}0.0863 * * * \\
(0.0222)\end{array}$ \\
\hline & & & & Ceiling & $-0.0401 * *$ \\
\hline
\end{tabular}


Table 10 (continued)

(1)

(2)

(3)

Time-invariant endogenous variables

\begin{tabular}{|c|c|c|c|c|c|}
\hline$N B F I$ & $\begin{array}{l}-0.0195 \\
(0.0362)\end{array}$ & Other & $\begin{array}{l}0.910 \\
(1.710)\end{array}$ & $E E C A$ & $\begin{array}{l}0.0201 \\
(0.0379)\end{array}$ \\
\hline$E E C A$ & $\begin{array}{l}-0.00700 \\
(0.0644)\end{array}$ & $E E C A$ & $\begin{array}{l}-0.0543 \\
(0.117)\end{array}$ & $L A C$ & $\begin{array}{l}0.124 * * * \\
(0.0200)\end{array}$ \\
\hline$L A C$ & $\begin{array}{l}0.125 * * * \\
(0.0461)\end{array}$ & $L A C$ & $\begin{array}{l}0.0973 \\
(0.0776)\end{array}$ & $E A P$ & $\begin{array}{l}0.142 \\
(0.106)\end{array}$ \\
\hline Ceiling & $\begin{array}{l}-0.0752 \\
(0.0720)\end{array}$ & Ceiling & $\begin{array}{l}-0.0273 \\
(0.0534)\end{array}$ & & \\
\hline Constant & $\begin{array}{l}0.1153 \\
(0.07170)\end{array}$ & Constant & $\begin{array}{l}0.0328 \\
(0.0746)\end{array}$ & Constant & $\begin{array}{l}0.0888 * * * \\
(0.0292)\end{array}$ \\
\hline sigma_u & 0.1201 & sigma_u & 0.1632 & sigma_u & 0.1086 \\
\hline sigma_e & 0.0577 & sigma_e & 0.0592 & sigma_e & 0.0529 \\
\hline rho & 0.8122 & Rho & 0.8836 & rho & 0.8083 \\
\hline $\begin{array}{l}\text { Wald Chi } 2 \\
\text { ( } p \text { value })\end{array}$ & $\begin{array}{l}1114.17 \\
(0.0000)\end{array}$ & $\begin{array}{l}\text { Wald Chi2 } \\
\text { ( } p \text { value })\end{array}$ & $\begin{array}{l}917.99 \\
(0.0000)\end{array}$ & $\begin{array}{l}\text { Wald Chi2 } \\
\text { ( } p \text { value })\end{array}$ & $\begin{array}{l}998.94 \\
(0.0000)\end{array}$ \\
\hline Sargan-Hansen & 0.0000 & Sargan-Hansen & 0.0000 & $\begin{array}{l}\text { Sargan-Hansen } \\
\text { ( } p \text { value })\end{array}$ & $\begin{array}{l}4.381 \\
(0.3569)\end{array}$ \\
\hline MFIs & 1327 & MFIs & 1183 & MFIs & 997 \\
\hline$N$ & 6172 & $N$ & 5274 & $N$ & 4199 \\
\hline
\end{tabular}

Standard errors in parentheses: $* p<0.10 ; * * p<0.05 ; * * * p<0.01$

considerably above marginal cost are perceived to have higher monopoly power and, therefore, charge higher interest rates. ${ }^{14}$ The impact of competition measured through the Lerner Index appears to be consistent across all models and subsamples. The coefficient estimates are all positive and economically and statistically significant except for the fixed effects framework with MFIs with a diamond rating between one and three (Table 6). Higher values of interest rates are associated with higher values of the Lerner Index. That is, MFIs that possess higher monopoly power tend to charge higher interest rates. ${ }^{15}$

Unlike Roberts (2013) and Baquero et al. (2018), this paper finds that both forprofit and nonprofit MFIs respond to competition similarly when using alternative measures of competition. This is an interesting result. While for-profit and nonprofit MFIs have different objectives, the results suggest that both types of MFIs follow similar strategies in response to competition. This may not come as a surprise given

\footnotetext{
${ }^{14}$ However, a high Lerner Index does not necessarily mean the MFI in question is exercising market power. Prices may exceed marginal costs for a number of reasons. For example, some MFIs may raise prices considerably above marginal costs to cover high fixed costs.

15 Interest rates and competition can be affected by omitted variables that fixed effects cannot fully account for such as lagged interest rate. The empirical results show that the impact the lagged interest rate is positive and statistically significant. The main findings do not change after including lagged interest rates. The inclusion of the lagged interest rate, however, leads a sharp decrease in the number of observations by more than 1000 . We therefore omitted this variable from the analysis.
} 
that lower interest rates allow both types of MFIs to reach more borrowers in pursuit of their objectives. Nonprofit MFIs may operate in a variety of settings, some involving competition with other nonprofit MFIs and some involving competition with for-profit MFIs. Services provided by for-profit and nonprofit MFIs can be considered as substitutes, which may influence both the interest rate that nonprofit MFIs charge and their appeal to donors. Available substitutes may lead nonprofit MFIs to reduce their operating expenses and interest rates. Nonprofit MFIs may vie with each other for socially oriented donors and reputation through the provision of credit to the poorest populations at concessional rates.

Unlike Vogelgesang (2003), McIntosh and Wydick (2005), McIntosh et al. (2005), and Assefa et al. (2013) the overall evidence of this paper follows the prediction of the structure-conduct-performance paradigm. The results suggest that competition reduces interest rates and that competition has no impact on various measures of default. If competition increases default, then interest rates will rise accordingly and profit margins will remain steady or even rise depending on the response of interest rates to default rates.

To test the impact of competition on default, three measures of default were obtained from the MIX Market for each MFI: portfolio at risk of more than 30 days, portfolio at risk of more than 90 days, and the write-off ratio. The estimates show that none of the three measures of competition are associated with higher default rates. To test the impact of competition on profit margins, we replaced interest rates with profit margin, net operating income compared to financial revenue, as the dependent variable in the regression analysis and the results show evidence that competition reduces profit margins, particularly for the Lerner Index. The underlying mechanism behind these results should be pellucid. Lower concentration in the microfinance industry leads to less monopolistic behaviour, which leads to lower interest rates and profit margins. ${ }^{16}$ Unlike the findings of Mersland and Strøm (2009), Roberts (2013) and Baquero et al. (2018), this paper's measures of competition yield intuitive and consistent results suggesting that competition may mitigate the problems of market power and offer borrowers microcredit at lower interest rates.

But do these findings depart from the structure-conduct-performance paradigm for nonprofit MFIs? The answer is yes if the only social goal of nonprofit MFIs is to provide credit at low interest rates. However, in addition to low interest rates, nonprofit MFIs also focus on additional social goals such as serving more women and reaching poorer clients (D'Espallier et al. 2013a, b, 2016; Al-Azzam 2019). Achieving these social goals simultaneously is challenging. While the interest rate offered and the percentage of women borrowers are straightforward to measure, reaching poorer clients is commonly measured through loan size per borrower drawing on the intuition that poorer borrowers tend to take smaller loans. Providing small loans (social objective) is costly and interest rates will rise consequently. Similarly, there is evidence that women face higher collateral requirements, receive smaller

16 The results of these regressions are not shown in this paper. 
Table 11 Social goals by MFI type

\begin{tabular}{lrlrlll}
\hline MFI status & Obs. & Interest rates & Obs. & $\begin{array}{l}\text { Percentage of } \\
\text { female borrowers }\end{array}$ & Obs. & $\begin{array}{l}\text { Average loan per bor- } \\
\text { rower/GNI per capita }\end{array}$ \\
\hline For-profit & 4761 & 0.25 & 4073 & 0.63 & 4609 & 0.2195 \\
Nonprofit & 5982 & 0.22 & 5337 & 0.67 & 5759 & 0.1658 \\
NGO & 3612 & 0.25 & 4553 & 0.77 & 4966 & 0.0905 \\
CU & 1636 & 0.17 & 1991 & 0.51 & 2334 & 0.3166 \\
Bank & 1302 & 0.19 & 1213 & 0.54 & 1489 & 0.3311 \\
NBFI & 3887 & 0.26 & 4656 & 0.62 & 5325 & 0.2038 \\
RB & 512 & 0.21 & 470 & 0.56 & 714 & 0.1666 \\
\hline
\end{tabular}

loans, and therefore pay higher interest rates (Fletschner 2009; Bellucci et al. 2010; Agier and Szafarz 2013).

Table 11 provides a summary of the interest rates, the percentage of female borrowers, and the average loan size per borrower relative to GNI per capita according the status of the MFI. On the aggregate and relative to for-profit MFIs, nonprofit MFIs charge lower interest rates, serve more women, and reach poorer borrowers. Among all types of MFIs, NGOs, registered as nonprofit MFIs, serve the greatest percentage of women and reach the poorest clients but charge relatively higher interest rates. Among all types of MFIs, cooperatives and credit union MFIs, registered as nonprofit MFIs, serve the lowest percentage of women and reach relatively few of the poorest borrowers, which enable them to charge the lowest interest rates. Banks, registered as for-profit MFIs, have a similar outlook as cooperatives and credit unions; they serve fewer women, reach far fewer of the poorest borrowers, and charge relatively low interest rates. Nonprofit MFIs with more monopoly power may achieve their social goals by serving more women and reaching poorer clients, both of which necessitate higher interest rates.

Should the strong relationship between competition and microcredit interest rates be interpreted as a causal effect of competition? While reverse causality cannot be ruled out, it is likely to be implausible. First, competition and interest rates would be interdependent if all MFIs were for-profit. Competition affects interest rates, and interest rates affect competition due to entry. In this case, endogeneity would be a serious concern. In the data sample, however, nonprofit MFIs make up 59\% of all MFIs. Since the goal of nonprofit MFIs is mainly poverty alleviation, their entry would not be based on the level of the presiding interest rates. In this case, the impact of interest rates on competition through entry would be implausible.

Tables 7 and 8 test the impact of competition on interest rates for both forprofit MFIs (Table 7) and nonprofit MFIs (Table 8). The results from Table 8, where reverse causality is highly unlikely, are similar to those in Table 7. This suggests that the potential of simultaneity bias, while it cannot be ruled out, might be less concerning. Second, the literature has well acknowledged that competition in non-experimental studies is likely to be endogenous for the parameters of interest (Blundell et al. 1999; Aghion et al. 2018). Busso and Galiani (2019) provided the first randomised controlled field experiment 
designed to assess the impact of increasing competition on prices of various goods in the Dominican Republic. They found that competition reduces prices and concluded that causality runs from competition to prices. Third, in the Hausman-Taylor estimates shown in Table 10, the Sargan-Hansen test of overidentification accepts the null assumption that the instruments set by the Hausman-Taylor estimator are exogenous.

Does a competitive microfinance industry enhance the welfare of borrowers? As stressed by De Quid et al. (2012), this question has been overlooked. The theoretical model of McIntosh and Wydick (2005) on the impact of competition predicts an aggravation of the asymmetric information problem, which leads to multiple loan taking, over indebtedness of borrowers, and less favourable loan contracts for borrowers. This conclusion, however, has not been well documented in the empirical literature. An exception is McIntosh et al. (2005) who find that competition induces a deterioration in repayment performance and a decrease in saving deposits of the borrowers. But does this process lead to higher interest rates? The evidence, including this work, suggests that competition lowers interest rates. Lower interest rates would help businesses produce enough profit to pay interest, increase borrower's income, accumulate assets and saving, repay on time, reduce the impact of adverse shocks, and enhance the overall well-being of the poor. The pool of the poor, however, may have less women borrowers and relatively wealthier clients. If the goal is to provide microcredit at lower interest rates, policymakers may consider enhancing the means for more competitive markets in microfinance, such as reducing the barriers to entry and prohibiting monopolistic practices. In doing so, policymakers may also need to establish formal information-sharing mechanisms or similar measures if the undesired consequences of competition arise, including multiple loan taking and over-indebtedness.

\section{Conclusion}

The microfinance industry has uniquely evolved over the years into one where for-profit MFIs compete side by side with nonprofit MFIs to extend financial services to the poor. According to the literature, this competition has led to multiple loan taking, over-indebtedness, and a higher probability of default. Higher rates of default would implicitly mean higher interest rates. The link between competition and interest rates, however, has not been well examined in the literature. The limited number of papers that link competition to interest rates have commonly deployed a single measure of competition finding inconclusive and (sometimes) counterintuitive results.

This paper uses three measures of competition to examine their impact on interest rates. These measures reflect three broad aspects of competition: geographical expansion, market concentration, and price markups. While the results for market concentration indicate that higher concentration is associated with higher interest rates, this impact is not consistently significant across all of the incantations we consider. Markups and geographical expansion, however, show a 
pervasive and economically significant impact on interest rates across nearly all of the models we investigate. MFIs that have relatively more branch offices and/ or higher values of the Lerner Index tend to charge higher interest rates. This conclusion is true for both for-profit and nonprofit MFIs.

The literature has well documented the adverse impacts of competition on the performance of MFIs. On the other hand, the overall impact of competition on the well-being of the poor has not been well examined in the literature. This paper concludes that competition reduces interest rates. Lower interest rates, in consequence, are an important element of the profitability of the micro-entrepreneurs and the well-being of their borrowers. The impacts of lower interest rates offered to the poor, however, need to be weighed against the adverse impacts of competition on other elements, such as over-indebtedness of borrowers, loan repayment, outreach, sustainability, and the financial health of MFIs. While the results of this paper do not provide clear answers to questions of how policymakers should exert influence on the domestic microfinance industry or which features of the appropriate regulatory environment should be manipulated, they do suggest that policymakers should expect lower interest rates as a result of regulatory frameworks that enhance competition among the domestic MFIs. Policy makers should be cautious in evaluating the level of competition in the microfinance industry. Alternative measures of competition can be negatively correlated and popular measures, such as the Herfindahl Index, may not adequately capture the competitive environment that MFIs operate in, leading to poor information concerning monopolistic behaviour. If the goal is to reduce interest rates, the results of this paper call for policy makers to be proactive in seeking measures that lay the foundations for a more competitive microfinance industry and incorporating formal information-sharing mechanisms. Achieving this goal, however, may mean serving less women and reaching wealthier clients that what might be socially optimal.

Acknowledgements Open Access funding provided by the Qatar National Library.

Open Access This article is distributed under the terms of the Creative Commons Attribution 4.0 International License (http://creativecommons.org/licenses/by/4.0/), which permits unrestricted use, distribution, and reproduction in any medium, provided you give appropriate credit to the original author(s) and the source, provide a link to the Creative Commons license, and indicate if changes were made.

\section{References}

Aghion P, Betchtold S, Cassar L, Herz H (2018) The causal effects of competition on innovation: experimental evidence. J Law Econ Organ 34:162-195

Agier I, Szafarz A (2013) Microfinance and gender: is there a glass ceiling on loan size? World Dev 42:165-181

Ahlin C, Lin J, Maio M (2011) Where does microfinance flourish? Microfinance institutions performance in macroeconomics context. J Dev Econ 95:105-120

Al-Azzam M (2019) Financing microfinance institutions: subsidies or deposit mobilisation. Appl Econ 51:1621-1633

Angelini P, Cetorelli N (2003) The effects of regulatory reform on competition in the banking industry. J Money Credit Bank 35:663-684

Armendariz De Aghion B, Morduch J (2005) The econoomics of microfinance. MIT Press, Cambridge 
Assefa E, Hermes N, Meeters A (2013) Competition and the performance of microfinance institutions. Appl Financ Econ 23:767-782

Bain J (1956) Barriers to new competition. Harvard University Press, Cambridge

Baltagi B (2005) Econometrics analysis of panel data, 3rd edn. Wiley, New York

Baquero G, Hamadi M, Heinen A (2018) Competition, loan rates and information dispersion in microcredit markets. J Money Credit Bank 50:893-937

Bardsley P, Meager R (2012) Competing lending platforms: Endogenous reputation in microcredit markets. Unpublished manuscript, University of Melbourne

Basharat B, Hudon M, Nawas A (2015) Does efficiency lead to lower prices? A new perspective from microfinance interest rates. Strateg Change Brief Entrep Finance 24:49-66

Bauchet J, Morduch J (2010a) Selective knowledge: reporting biases in microfinance data. Persp Glob Dev Technol 9:240-269

Bauchet J, Morduch J (2010b) Selective knowledge: reporting biases in microfinance data. Persp Glob Dev Technol 9:240-269

Beck N (2001) Time-series-cross-section data: what have we learned in the past few years? Annu Rev Polit Sci 4:271-293

Bella Di G (2011) The impact of the global financial crisis on microfinance and policy implications. IMF Working Paper 11/175, Washington DC

Bellucci A, Borisov A, Zazzaro A (2010) Does gender matter in bank firms relationships? Evidence from small business lending. J Bank Finance 34:2968-2984

Bikker J, Haaf K (2002) Measures of competition in the banking industry. Econ Financ Model 9:53-98

Blundell R, Griffith R, Reenen J (1999) Market share, market value and innovation in a panel of British manufacturing firms. Rev Econ Stud 66:529-554

Buera F, Kaboski J, Shin Y (2012) The macroeconomics of microfinance. NBER Working Paper 17905

Busso M, Galiani S (2019) The causal effect of competition on prices and quality: field experimental evidence. Am Econ J Appl Econ 11:33-56

Caudill S, Gropper D, Hartarska V (2012) Microfinance institution costs: effects of gender, subsidies and technology. J Financ Econ Policy 4:292-304

Cull R, Demirgüç-Kunt A, Morduch J (2009) Microfinance meets the market. J Econ Perspect 23:167-192

De Quid J, Fetzer T, Ghatak M (2012) Microfinance, market structure, and borrower welfare: regulatory lessons from the Indian crisis. London School of Economics, Working Paper

de Quidt J, Fetzer T, Ghatak M (2018) Commercialization and the decline of joint liability microcredit. J Dev Econ 134:209-225

Dehejia R, Montgomery H, Morduch J (2012) Do interest rates matter? Credit demand in the Dhaka slums. J Dev Econ 97:437-449

D'Espallier B, Szafarz M, Hudon A (2013a) Unsubsidized microfinance institutions. Econ Lett 120:174-176

D’Espallier G, Guérin I, Mersland R (2013b) Women and repayment in microfinance: a global analysis. World Dev 39:758-772

D'Espallier B, Hudon M, Szafarz A (2016) Aid volatility and social performance in microfinance. Nonprofit Volunt Sect Q 46:116-140

D'Espallier B, Goedecke J, Hudon M, Mersland R (2017) From NGOs to Banks: does institutional transformation alter the business model of microfinance institutions? World Dev 89:19-33

Emran S, Morshed M, Stiglitz J (2011) Microfinance and missing markets. MPRA Paper No. 41451

Fernandez de Guevara J, Maudos J, Perez F (2005) Market power in European banking sectors. J Financ Serv Res 27:109-137

Fletschner D (2009) Rural women's access to credit: market imperfections and intrahousehold dynamics. World Dev 37:618-631

Gonzalez A (2007) Resilience of microfinance institutions to macroeconomic events: an econometrics analysis of MFI asset quality. MIX Discussion Paper No. 1, The MIX

Guggenberger P (2010) The impact of a Hausman pretest on the size of a hypothesis test: the panel data case. J Econom 156:337-343

Hartarska V, Nadolnyak D (2007) Do regulated microfinance institutions achieve better sustainability and outreach? Cross-country evidence. Appl Econ 39:1207-1222

Hartarska V, Parmeter C, Nadolnyak D, Zhu B (2010) Economies of scope for microfinance: differences across output measures. Pac Econ Rev 15:464-481 
Hartarska V, Shen X, Mersland R (2013) Scale economies and input price elasticities in microfinance institutions. J Bank Finance 37:118-131

Hausman A, Taylor E (1981) Panel data and unobservable individual effects. Econometrica 49:1377-1398

Helmes B, Reille X (2004) Interest rate ceilings and microfinance: the story so far. CGAP Occasional Paper 9, Washington, DC

Hermes N, Lensink R, Meeters A (2018) Financial development and the efficiency of microfinance institutions. In: Spence J, Frynas G, Muthuri J, Navare J (eds) Research handbook on small business social responsibility: global perspectives. Edward Elgar Publishing, Cheltenham, pp 177-201

Honohan P (2004) Financial sector policy and the poor: selected findings and issues. World Bank Working Paper No. 43

Kar AK (2016) Measuring competition in microfinance markets: a new approach. Int Rev Appl Econ 30:423-440

Kasman S, Kasman A (2015) Bank competition, concentration and financial stability in the Turkish banking industry. Econ Syst 39:502-517

Kevane M, Wydick B (2001) Microenterprise lending to female entrepreneurs: sacrificing economic growth for poverty alleviation? World Dev 29:1225-1236

Khandker S, Baqui K, Khan Z (1995) Grameen bank: performance and sustainability. Discussion Paper No. 306. World Bank, Washington, DC

Maudos J, Fernandez de Cuevara J (2007) The cost of market power in banking: social welfare loss vs. cost inefficiency. J Bank Finance 31:2013-2025

McIntosh C, Wydick B (2005) Competition and microfinance. J Dev Econ 78:271-298

McIntosh C, de Janvry A, Sadoulet E (2005) How rising competition among microfinance affects incumbent lenders. Econ J 115:987-1004

Mersland R, StrØm R (2009) Performance and governance in microfinance institutions. J Bank Finance 33:662-669

Mersland R, StrØm R (2010) Microfinance mission drift. World Dev 38:28-36

Mersland R, Strøm R (2013) What drives the microfinance lending rate? Working Paper

MicroBanking Bulletin 2 I (n.d.)

Miller H (2013) Interest rate caps and their impact on financial inclusion. Economic and Private Sector, Professional Evidence and Applied Knowledge Services

Murphy K, Topel R (1985) Estimation and inference in two-step econometric. J Bus Econ Stat 3:370-379

Naimbo S, Gallegos C (2014) Interest rate caps around the world: still popular, but a blunt interestrument. Policy Research Working Paper, World Bank

Pagan A (1984) Econometric issues in the analysis of regressions with generated regressors. Int Econ Rev 25:221-247

Porteous N (2006) Competition and microcredit interest rates. CGAP Focus Note No. 33

Roberts P (2013) The profit orientation of microfinance institutions and effective interest rates. World Dev 41:120-131

Rosenberg R, Gonzales A, Narain S (2009) The new moneylender: are the poor being exploited by high microcredit interest rates? CGAP Occational Paper No. 15

Schicks J, Rosenberg R (2011) Too much microcredit? A survey of the evidence on over-indebtness. CGAP Occastional Paper No. 19

Sinclair H (2012) Confessions of a microfinance heretic: how microlending lost its way and betrayed the poor. Berrett-Koehler Publishers Inc, San Francisco

Stiglitz J, Wiess A (1981) Credit rationing in markets with imperfect information. Am Econ Rev 71:393-410

Van Rooyen C, Stewart R, de Wet T (2012) The impact of microfinance in Sub-Saharan Africa: a systematic review of the evidence. World Dev 40:2249-2262

Vogelgesang U (2003) Microfinance in times of crisis: the effects of competition, rising indebtedness and economic crisis on repayment behavior. World Dev 31:2085-2114

Wagennar K (2014) Institutional transformation and mission drift in microfinance. Working paper. Center of Development Studies, University of Cambridge, UK

Publisher's Note Springer Nature remains neutral with regard to jurisdictional claims in published maps and institutional affiliations. 